\title{
Desulfurization of Thar Lignite by Oxidative Alkali Leaching Under Pressure
}

Muhammad Azam Usto ( $\square$ muhammadusto729@gmail.com )

Dawood University of Engineering and Technology

Arshad lqbal Jarwar

Dawood University of Engineering and Technology

Ghulamullah Maitlo

Dawood University of Engineering and Technology

Shaoib Ahmed Qureshi

Dawood University of Engineering and Technology

Sikandar Ali Abbasi

Dawood University of Engineering and Technology

Shahab Alam

Dawood University of Engineering and Technology

\section{Zubair Hashmi}

Dawood University of Engineering and Technology

Abdul Karim Shah

Dawood University of Engineering and Technology

\section{Aqeel Ahmed Shah}

NED University of Engineering and Technology

Abdul Sattar Jatoi

Dawood University of Engineering and Technology

Ghulam Abbas Kandharo

Dawood University of Engineering and Technology

\section{Shah Rukh Memon}

Dawood University of Engineering and Technology

\section{Research}

Keywords: Coal desulfurization, Alkali leaching, Pyritic sulfur, Organic sulfur

Posted Date: February 9th, 2021

DOI: https://doi.org/10.21203/rs.3.rs-190766/v1 
License: (c) (i) This work is licensed under a Creative Commons Attribution 4.0 International License. Read Full License 


\section{Abstract}

Pakistan is the world largest lignite bearing country in the world due to the Thar coal reserves. Sulfur contained in this coal need to be removed prior to combustion. Oxidative alkali leaching in dissolved oxygen technique was used to remove the sulfur from Thar coal. This method removed enough all three types of sulfur; about $90 \%$ pyretic sulfur, $78 \%$ organic sulfur and $50 \%$ sulfate sulfur and more than $82 \mathrm{~S} \%$ of total sulfur removal was achieved. Effect of various reaction parameters were observed, it was investigated that reaction time and partial pressure of oxygen has positive effect on the desulfurization, higher the reaction time and oxygen partial pressure higher the degree of desulfurization, also the desulfurization increased with increase in reaction temperature and alkali concentration till some optimum value and then decreases with further increase in value of temperature and concentration of alkali, although desulfurization was observed maximum with minimum particle size. Coal was also characterized with Thermogravimetric Analysis (TGA) and Testo smoke number to investigate the combustion behavior of processed coal. It was observed that combustion properties of processed coal were improved and black smoke in processed coal was reduced.

\section{Introduction}

Coal is highly abundant fossil fuel on the earth surface and has been used since long, it is about $70 \%$ of total known fossil fuel resources in the world(Franco and Diaz 2009), even it is reported that the coal reserves are more than other fossil fuel like oil and gas, that are more than enough to face the present energy requirement (Rehman et al. 2018), and still it is fulfilling the requirement of the energy generation. About more than $40 \%$ of electric power plants are utilizing the coal fuel (Meshram et al. 2015). Pakistan is the $7^{\text {th }}$ largest country in coal reserves, about 186 billion tons sedimentary rock fossil fuel (coal) is present in Pakistan and mostly $97 \%$ is lignite coal (Malkani 2012), hence Pakistan becomes the top lignite coal bearing country in the world .Thar is largest coal mine in the country, about 175,506 million tons of coal is estimated. Thar coal field spreads over $9000 \mathrm{~km}^{2}$ and has 20 maximum coal seams, ultimate and proximate composition of the coal varies with block to block and with different depth (Malkani and Malik 2018).Before the discovery of Thar coal field Pakistan was not appeared in the list of coal rich countries (Munir et al. 2018). As Thar lignite coal contains the variable amount of sulfur with respect to block and depth the presence of sulfur in coal may enhance the calorific value of coal, but it causes the serious destruction to ecological system as production of SOx and hydrogen sulfide during combustion. Therefore it is needed to remove or reduce the Sulphur amount from coal (S. Mukherjee and Borthakur 2001).

Sulfur in coal is present in different forms, like inorganic Sulfur (mostly in the form of pyrite), organic Sulfur (mostly present in trace amounts). Organic Sulphur in coal is present as thiol, sulfide, thiophenol, and disulfide; however, almost $95 \%$ of the organic Sulfur is in the form of thiophenes and sulfate sulfur present in different ranges (Kozłowski, Wachowska, and Yperman 2003). Coal desulfurization prior to combustion is an important technology to avoid air pollution (Prasassarakich and Thaweesri 1996).Sulphur is covalently bonded with carbon (C-S bond) in these compounds, this bond is difficult to 
breakdown by any physical process, hence it requires chemical processing for cleaving of the bond for Sulphur removal.

Chemical leaching is an effective way for desulfurization and demineralization. Chemical leaching has ability to remove the minerals that strongly bound to the coal, and that cannot be removed easily with physical method (Samit Mukherjee and Borthakur 2003). Repetition of chemical leaching process causes reduction in the organic sulfur content due to the breakage of C-S bonds, which tends to decrease or even eliminate sulfur from the coal(Kozłowski, Wachowska, and Yperman 2003). Samit has observed that alkali leaching is highly effective for pyritic sulfur removal, he leached the Indian coal with $\mathrm{KOH} 16 \%$ solution followed by acid treatment at $150^{\circ} \mathrm{C}$, about $90 \%$ inorganic sulfur and $11 \%$ organic sulfur could be removed. He stated that demineralization of Indian coal was not found as high as with $\mathrm{NaOH}$, because $\mathrm{KOH}$ treatment needs acid treatment followed by the alkali treatment, only potassium hydroxide could not remove that sufficient amount of pyrite, also potassium aluminosilicate is formed, and traces of potassium remains with coal (Samit Mukherjee and Borthakur 2003). The similar phenomenon was observed by the Sharma (Sharma and Gihar 1991). The pyrite removal by $\mathrm{NaOH}$ leaching was also observed by Li and Cho, it was found that more than $70 \%$ of pyritic sulfur in Pittsburgh No. 8 coal was removed at the conditions of $0.4 \mathrm{M}$ hypochlorite, $0.4 \mathrm{M} \mathrm{NaOH}$, and $90^{\circ} \mathrm{C}, 37.8 \%$ of organic sulfur in Illinois No. 6 coal was removed at the conditions of $0.4 \mathrm{M}$ hypochlorite with room temperature, followed by hydrolysis at $0.3 \mathrm{M} \mathrm{NaOH}$ and at $90^{\circ} \mathrm{C}$ (Xia and Xie 2017). Mursito performed leaching under pressure (hydrothermal treatment) of Banten Indonesian high sulfur coal. The total sulfur was reduced up to $70 \%$ by hydrothermal processing without the addition of $\mathrm{NaOH}$ during the desulfurization process. However, after the addition of $0.025 \mathrm{~mol} / \mathrm{g}$ concentration of $\mathrm{NaOH}$, the total sulfur content was reduced from 3.1 to $0.3 \%$, which showed a 90\% reduction in the total sulfur content (Mursito, Hirajima, and Sasaki 2011).

Waugh (Waugh Aand Bowing 1984) used the method of pressure leaching on the coal with 2.5 molarity of $\mathrm{NaOH}$ solution at $200^{\circ} \mathrm{C}$ with particle size of $200 \mu \mathrm{m}$ for 40 minutes, he achieved $90 \%$ demineralization. Michael has worked on the mechanism of organic sulfur removal from coal by sodium hydroxide $\mathrm{NaOH}$, he observed that alkali metal cation are more effective to decompose the thiophenes and furan of organic sulfur present in the coal, hence the alkali hydroxide has ability to remove not only pyritic sulfur but also organic sulfur (Nowak et al. 1989). Oxidative desulfurization is promising technology for removing sulfur from coal at lower temperature and in economical way (Saikia, Khound, and Baruah 2014). Oxidative desulfurization is an effective way to remove most of the pyritic sulfur as well as organic sulfur (Taylor, n.d.),

The reaction of pyritic desulfurization is given by the equation 1 and 2 . In first step pyrite reacts with dissolved oxygen and forms the precipitate layer of hematite and sulfuric acid, then sulfuric acid immediately neutralizes with alkali $(\mathrm{NaOH})$ and produces sodium sulfate and water. The sodium sulfate is soluble in water and hematite forms precipitate in the solution. 


\section{$2 \mathrm{FeS}_{2}++7.5 \mathrm{O}_{2}+4 \mathrm{H}_{2} \mathrm{O} \rightarrow \mathrm{Fe}_{2} \mathrm{O}_{3}+4 \mathrm{H}_{2} \mathrm{SO}_{4}$ $\mathrm{H}_{2} \mathrm{So}_{4}+2 \mathrm{NaOH} \rightarrow \mathrm{Na}_{2} \mathrm{SO}_{4}+2 \mathrm{H}_{2} \mathrm{O}$}

Pyrite is naturally effective to react with water and oxygen (Chiri and Schlegel 2017). Chuang (Taylor, n.d.) reported that rate controlling step is the diffusion of oxygen through the product hematite $\left(\mathrm{Fe}_{2} \mathrm{O}_{3}\right)$ layer at temperature from $120^{\circ} \mathrm{C}$ to $180^{\circ} \mathrm{C}$ and partial pressure of oxygen from $0.41 \mathrm{MPa}$ to $1.04 \mathrm{MPa}$.

It was also observed by J.E Andersen (Andersen, Halpern, and Samis 1953) while he was leaching the galena with sodium hydroxide he concluded the kinetics of chemical reaction that, reaction of metallic sulfide (PbS) with Oxygen is in first step, while neutralization with alkali sodium has secondary effect on kinetics of reaction arising from its influence on the solubility and transport of oxygen with in the solution, and also hydrate (water) is the product of the reaction due to the neutralization. He calculated the activation energy for the reaction to be 6300 calory per mole.

K C(Chuang, Markuszewski, and Wheelock 1983) Chuang leached the American coal in oxygen and in air by oxidation in alkaline $(\mathrm{NaOH})$ solution. He observed that rate of reaction (oxidation reaction) was proportional to the oxygen partial pressure, hence he decided that in first step pyrite reacts with oxygen forms hematite and sulfuric acid and then immediately this acid is to be neutralized with alkali, the reaction was first order reaction. Tao has performed the reaction between pyrite and dissolved oxygen in water and calculated the , the activation energy was $12.2 \mathrm{Kcal} / \mathrm{mole}$ (Tao, Graves, and Wheelock 1977) for chemical reaction between the dissolved oxygen and pyrite. Same observations were found by CY Tai, he leached the coal with sodium carbonate in dissolved oxygen. He also observed that oxygen reacts with pyrite in first step and then alkali neutralized the sulfuric acid produced with pyrite and oxygen reaction. Mketo (Mketo, Nomngongo, and Ngila 2017) performed the leaching of South Africa coal with sodium hydroxide and hydrogen peroxide (as oxidative agent) and found that it could reduce the sulfur of raw coal up to $55 \%$.

JB Joshi (Струков and Леванюк 1983) has observed that pyrite oxidation reaction is the intrinsic chemical reaction between the dissolved oxygen and pyrite, he calculated the activation energy as $35 \times 10^{3} \mathrm{KJ} / \mathrm{mole}$. He observed that the fine particle size requires less reaction time for the conversion of pyrite as compared to coarse particle size. The desulfurization of coal with oxidative method highly reduces its corrosive effects (Ahmad et al. 2019)

\section{Organic sulfur}

Although the alkali leaching either alone or with dissolved oxygen is very effective for pyritic sulfur removal, yet it can also remove the organic sulfur, in this work about $78 \%$ organic sulfur could be removed (at alkali concentration of 0.25 molarity, partial pressure of oxygen of 200 psi, reaction time of 4 hours, at temperature $120^{\circ} \mathrm{C}$, and with particle size of $40 \mu \mathrm{m}$ ).. Ca Michael (Nowak et al. 1989) worked on the mechanism of organic sulfur removal from coal by sodium hydroxide $\mathrm{NaOH}$, he observed that alkali 
hydroxide containing large alkali metal cation are more effective in decomposition of thiophenes and furan of organic sulfur present in the coal. B.R Utz (Utz, Friedman, and Soboczenski 1986) found the chemistry of molten alkali hydroxide for organic species in the coal. He used the mixture of $\mathrm{NaOH}$ and $\mathrm{KOH}$ to study the organic sulfur species in the coal, he selected benzothiophene and dibenzothiophene as model compounds that simulated the organosulfur compounds in the coal. He analyzed, the mechanism of desulfurization involves thiophene ring opening to form an aromatic thiol that produces desulfurization process, desulfurization was accrued by sodium thiophenolate or potassium thiophenolate although water has minimum or no role in the organic sulfur removal.

Most of the oxygen that reacts with the organic matrix remains attached as hydroperoxides and their decomposition products. Lui(Liu et al. 2008) achieved the removal of $73 \%$ organic sulfur, and $83 \%$ pyritic sulfur by alkali leaching of Yangzhou (Eastern China) in dissolved oxygen and then further treated with acid reflux. He stated that loss of organic sulfur may be occurred due to removal of thiols compounds present in the coal that are very attractive to oxidation, they are easily converted to the disulfides under basic condition. He observed that mostly organic sulfur compounds on oxidation produces sulfoxides, sulfones, sulfonic acids, sulfonic acid and sulfenic acid depending upon the nature of organic compound and oxidizing agent and conditions, although $\mathrm{S}=0$ group is common in the oxidized products. $\mathrm{M}$.

Kozloski(Kozłowski, Wachowska, and Yperman 2003) observed that C-S breaks and aliphatic thiols forms as precipitation in the solution (but these aliphatic thiols are different from the thiols that are present in organic sulfur) further these aliphatic thiols are to be converted into the soluble sulfides. He concluded and practically proved that coal do not contains the non-volatile aliphatic thiols. He worked on the Spanish coal Maquinna and American coal Illinois No.6, and leached the coal with potassium liquid ammonia solution. A detail mechanism of oxidation of organic disulfides was investigated by the Rois Benassi(Benassi, Fiandri, and Taddei 1997) he stated that oxidation of organic disulfides proceeds via steps of intermediates leading to sulfonic acid as final product, also desulfurization of coal thiols carried out in similar manner. Oxidative leaching is effect for removing the all types sulfur up to higher percentage.

\section{Materials And Method}

Coal was collected from the site of Thar coal, lumps were crushed in jaw crusher, the crushed coal was dried in an oven at $110^{\circ} \mathrm{C}$ and then ground in ball mill to get pulverized coal. The pulverized coal was screened through standard sieving process to get different particle size from $30 \mu \mathrm{m}-40 \mu \mathrm{m}$ to $200 \mu \mathrm{m}$ $400 \mu \mathrm{m}$. A basic solution of $\mathrm{NaOH}$ was prepared in distilled water with different concentrations from 0.1 Molarity to 1 Molarity for different runs of the experiment.

Raw coal was characterized by ultimate and proximate analysis and heating values to study the coal. The sulfur was determined by D2492, proximate analysis by D7582, Ultimate analysis by D3176, and gross calorific value of coal by D5868, that was $3624.55(\mathrm{Kcal} / \mathrm{Kg})$. At the end raw coal and products were characterized with thermogravimetric analysis, and Testo smoke number to study the combustion behavior of coal. 
An isothermal hot jacketed tank reactor was used to perform this reaction, manufactured by Edibon International. The total capacity of the reactor was about 3 lit. The tank was jacketed with hot paraffin oil circulation to achieve and maintain the required temperature. The hot paraffin oil was circulated by centrifugal pump fixed at the base unit and was heated by immersed electrical heater in hot oil tank. A three-stage agitator was immersed into the reactor tank to agitate the solution, powered by a motor with speed regulator. Reactor tank has different valves for Oxygen, for reactant inlet, for product outlet and for sampling. In this experiment the solution and raw coal were fed manually. The temperature of circulating oil and reacting solution were taken with thermocouple and their reading was displayed on attached computer. The flow rate of oxygen was measured by rotameter installed in equipment.

Pulverized coal and prepared basic solution were poured into the reactor manually from the top of the reactor tank. The heater was kept on heating circulating oil until the reaction temperature was achieved and oxygen flow was started. The reaction time for the process was different for each run. As soon as the reaction was achieved, circulation of hot oil, gas flow and agitator all were turned off and solution was cooled at room temperature and product was withdrawn from the reactor. The solution was filtered with grade 1 filter paper to separate filtrate liquid and coal cake. Coal was washed with distilled water and airdried for 24 hours and then oven dried at $110^{\circ} \mathrm{C}$ and then characterized in laboratory.

Table 1 Ultimate and proximate analysis of Thar raw coal

\begin{tabular}{|llllllllllll|}
\hline \multicolumn{1}{|c|}{ Proximate Analysis } & \multicolumn{1}{l|}{ Ultimate Analysis } \\
\hline M & C & V & A & C & N & H & O & Sp & Ss & So & St \\
\hline 16.84 & 33.13 & 24.53 & 18.19 & 55.59 & 0.84 & 2.05 & 33.86 & 1.78 & 0.1 & 0.3 & 2.17 \\
\hline
\end{tabular}

Moisture is on air dried basis, and $\mathrm{C}, \mathrm{N}, \mathrm{H}$, and $\mathrm{O}$ are on dry and ash free basis

\section{Results And Discussion}

\subsection{Effect of alkali concentration}

A series of runs were conducted to observe the effect of alkali concentration on desulfurization of Thar coal. The pulverized coal of particle size $40 \mu \mathrm{m}$ was treated with the different concentrations of $\mathrm{NaOH}$ taken from 0.1 Molarity to 0.4 Molarity. Temperature was kept constant at $120^{\circ} \mathrm{C}$ while reaction time was maintained for 1.5 hour, the dissolved oxygen partial pressure was $50 \mathrm{psi}$ and 100 psi respectively. It was observed that pyritic sulfur reduction while treating only with distilled water was $34 \%$. The maximum pyrite removal was about $67 \%$ at $0.25 \mathrm{M}$ and 50 psi partial pressure of oxygen. Furthermore, at $100 \mathrm{psi}$ pyritic removal was about $70.3 \%$ and total sulfur removal was improved from $51 \%$ to $55.5 \%$. Organic sulfur reduction was $32 \%$ at $50 \mathrm{psi}$ and $0.25 \mathrm{M}$ and increased up to $35 \%$ sulfur reduction at $100 \mathrm{psi}$ and at $0.25 \mathrm{M}$. The maximum sulfate sulfur reduction was $35 \%$ at $100 \mathrm{psi}$ and 0.25 Molarity as shown in figure 2(a) and figure 2(b). Maximum sulfur reduction was occurred at 0.25 molarity of $\mathrm{NaOH}$ and further 
increase in molarity of $\mathrm{NaOH}$ showed decrease in sulfur reduction. Hence the $0.25 \mathrm{Molarity}$ of $\mathrm{NaOH}$ was found as optimum value for alkali concentration for this reaction.

It was observed that rate of coal desulfurization was increased with increase in concentration of alkali solution till optimum value of $2.5 \mathrm{Molarity}$ of $\mathrm{NaOH}$, and at higher concentration of alkali, the sulfur content in coal starts to increase, means the desulfurization tends to reduce as shown in figure 3(a) and figure 3(b). Similar behavior was observed by the Mukherjee (S. Mukherjee and Borthakur 2001), while leaching the Makum (Assam India) coal with different concentrations of $\mathrm{NaOH}$, he found demineralization of coal was increased with increase in alkali concertation, till optimum value and then it tends to reduce due to formation of $\left[\mathrm{Na}_{\mathrm{a}}\left(\mathrm{AlO}_{2}\right)_{\mathrm{b}}\left(\mathrm{SiO}_{2}\right)_{\mathrm{c}} \mathrm{NaOH} . \mathrm{H}_{2} \mathrm{O}\right]$ sodium aluminosilicate precipitates. $\mathrm{E}$. Andersen reported the decrease in demineralization degree due to increase in alkali concertation after optimum values owing to to less solubility of oxygen at higher concertation of alkali (Andersen, Halpern, and Samis 1953). He performed the oxidative sodium hydroxide leaching on galena crystal from ViolaMac mines Sandon and observed that solubility of oxygen reduced at higher concentration of $\mathrm{NaOH}$. TD Wheelock performed leaching of US coal in dissolved oxygen, and observed that desulfurization increases with increase in alkali concentration till optimum value ( 0.35 Molarity of sodium carbonate), and then at higher value of alkali concentration it tends to reduce rapidly (Wheelock 1981).

Mukherjee had reacted the Boragolai and Ledo (Indian) coal with sodium hydroxide, he observed that the desulfurization of coal increases with increase in alkali concentration from $2 \%$ to $8 \% \mathrm{NaOH}$ solution, while at $16 \%$ it starts to decrease in Boragolai coal. He also noted that $\mathrm{NaOH}$ was more effective for pyritic sulfur removal as compared to organic and sulfate sulfur removal (Samit Mukherjee and Borthakur 2004).

\subsection{Effect of reaction time}

A series of different experiments were performed to study the effect of oxidative leaching time on Thar coal desulfurization. During reaction (leaching), coal particle size was $40 \mu \mathrm{m}$, molarity of $\mathrm{NaOH}$ was 0.25 , the temperature was $120^{\circ} \mathrm{C}$. While oxygen pressure was fixed at 50psi and 100 psi for each run respectively. And reaction time was from half hour to 4 hours, eight experiments were conducted with difference of 30 minutes to study the behavior of reaction time on desulfurization. It was observed that influence of time on sulfur removal was uniform, i.e. with increase in reaction time, desulfurization was also increased. Although the rate of desulfurization in pyrite was higher than that of organic and sulfate sulfur reduction as shown in figure 4(a) and figure 4(b).

At maximum time of 4 hours, around $72.6 \%$ pyrite was reduced at $50 \mathrm{psi}$, and $74 \%$ pyrite was removed at 100 psi. Maximum organic sulfur reduction was $48 \%$ and sulfate sulfur reduction was $50 \%$. And total sulfur reduction was achieved up to $62.8 \%$ as shown in figure $5(a)$ and figure $5(b)$.

The behavior of higher sulfur reduction due to higher reaction time was also investigated by Mukherjee and Borthakur (Samit Mukherjee and Borthakur 2004). He noted that rate of desulfurization was increased with increase in leaching time. Rehman and Waqar (Rehman et al. 2018) observed the similar 
effect in leaching the Chola Saidan Shah coal, they used the Quadratic module response (ANOVA) to analyze their experimental data. They observed that increasing the reaction time increases the degree of desulphurization, he concluded his results that when coal particle remained within the hot alkali solution for longer time the more sulfur removal occoured. Husein Kara (Kara and Ceylan 1988) treated four Turkey coals (Beysehir, Dadagi, Ermenek and Ilgin) with $\mathrm{NaOH}$. He observed that Dadagi coal and Beysehir coal showed increase in desulfurization of coal with increase in treatment time.

M. Guru (Ahmad et al. 2019) leached the Turkey Askale coal with nitric acid as oxidant agent and he observed that desulfurization increased with increase in leaching time, concentration of nitric acid was $65 \%$ the optimum leaching time was 16 minutes and he removed about $40 \%$ sulfur from Askale coal.

\subsection{Effect of particle size}

Four experiments were conducted to observe the effect of particle size on desulfurization. Different particle size for each experiment were selected ranging from $40 \mu \mathrm{m}$ to $400 \mu \mathrm{m}$ and all other parameters were kept constant. The partial pressure was 100 psi, treatment time was 2 hours, $\mathrm{NaOH}$ concentration was 0.25 Molarity, and temperature was $120^{\circ} \mathrm{C}$. It was observed that desulfurization decreased with increase in Thar coal particle size, or in other words at smaller particle size, the rate of desulfurization was higher. The amount of sulfur content with respect to the particle size is shown in figure 6.

Joshi observed that the fine particle size requires less reaction time for the conversion of pyrite to ferric oxide as compared to coarse particle size (Струков and Леванюк 1983). Faraz Anwar (Anwar et al. 2020) leached the coal (from Jehlum district) with potassium hydroxide with different particle size from 60 to 220 meshes, he observed that when particle size was decreased the rate of desulfurization was increased, he removed as maximum as $75 \%$ of total sulfur. Pattarapan (Prasassarakich and Thaweesri 1996) treated the Mae Moh coal (from Lampang Thailand) with sodium Benz oxide, he also observed that amount of desulfurization increases with decrease in particle size, he used the particle size from $250 \mu \mathrm{m}$ to $850 \mu \mathrm{m}$, temperature from $190^{\circ} \mathrm{C}$ to $250^{\circ} \mathrm{C}$. He was able to remove sulfate and pyritic sulfur from $65 \%$ to $85 \%$. However organic sulfur removal was up to $30 \%$. He concluded that rate of reaction was inversely proportional to the coal particle size, he also observed that mass transfer rate was inversely proportional to square root of coal particle size, however an optimum particle size should be decided for desulfurization, because a sufficient amount of energy is required for grinding and weighing of coal during size reduction. Chuang (Chuang, Markuszewski, and Wheelock 1983) observed that Time for complete conversion of $\mathrm{FeS}_{2}$ to hematite depend up on the square root of particle size. Guru(Gürü, Sariöz, and Çakanyildirim 2008) performed the leaching of Turkey coal with $\mathrm{H}_{2} \mathrm{O}_{2}$ as oxidative agent, he observed that rate of desulfurization was decreased with increase in particle size, the minimum particle size in his experiment was $0.25 \mathrm{~mm}$ and larger was $0.45 \mathrm{~mm}$ and the reaction time was 12 hours.

\subsection{Effect of temperature}

The effect of temperature on desulfurization of Thar coal by oxidative alkali treatment is shown in figure $7(a)$ and $7(b)$, different experiments were conducted to investigate the effect of temperature on 
desulfurization. It was observed that degree of desulfurization was increased with increase in temperature till an optimum value, then it tends to reduce. The optimum value for temperature was $120^{\circ} \mathrm{C}$ and other parameters were; particle size $40 \mu \mathrm{m}$, time was 1.5 hour and 3 hours, partial pressure of oxygen was 100 psi and agitation speed was 700rpm, flow rate of oxygen was 1.2 liters per minute, the ratio of Thar coal to alkali solution was 50 grams of coal in $500 \mathrm{ml}$ of alkali solution, the maximum sulfur reduction was observed at temperature of $120^{\circ} \mathrm{C}$.

At 1.5 hour pyrite sulfur reduction was about $70.3 \%$, organic sulfur reduction was $44 \%$, sulfate sulfur was $35 \%$ while total sulfur reduction was achieved about $57 \%$. Although at 3 hour time and at $120^{\circ} \mathrm{C}$ temperature the pyritic sulfur reduction was improved up to $80.6 \%$, organic sulfur reduction up to $66 \%$ and sulfate sulfur up to $45 \%$, while total sulfur was reduced up to $70 \%$ as shown in figure 8 (a) and 8 (b). The decrease in desulfurization at higher temperature (more than $120^{\circ} \mathrm{C}$ ) may be due to the lower solubility of oxygen at higher temperature as reported by T.D Wheelock (Wheelock 1981). The similar effect was observed by Waqas Ahmed (Ahmad et al. 2019) that desulfurization of coal was increased till an optimum value and then it tends to reduce, he selected the Lakhra coal for his study, he treated the Lakhra coal with three different alkali compounds sodium hydroxide, sodium carbonate, and potassium hydroxide at different concentrations, time and temperatures. He investigated that its optimum temperature was $40^{\circ} \mathrm{C}$ and about $50 \%$ sulfur was removed at that temperature, although at higher temperature desulfurization tends to reduce. This behavior of temperature was also observed by Semra Karaca (Karaca and Akyu 2003), he leached the Askale Turkish coal with nitric acid as an oxidative agent at different temperatures and observed that desulfurization was increased with increase in temperature and it was started to reduce at higher temperature. He found that the optimum temperature was $103^{\circ} \mathrm{C}$ at $25 \%$ solution of nitric acid. He investigated that at higher temperature the leaching agent starts to destroy. At initial stage an increment in desulfurization with increase in temperature was observed and then an equilibrate was observed by Zhiling Li (Li, Sun, and Jia 2010).

\subsection{Effect of partial pressure of oxygen}

The partial pressure shows a great influence on the desulfurization, a sufficient reduction in all pyritic, sulfate and organic sulfur was observed at higher value of partial pressure of oxygen. About 5 different experiments were conducted to study the behavior of oxygen partial pressure. The pressure of oxygen was from $25 \mathrm{psi}$ to $200 \mathrm{psi}$, while other parameters were constant as; temperature was $120^{\circ} \mathrm{C}$, concentration of $\mathrm{NaOH}$ was $0.25 \mathrm{Molariy}$, particle size was $40 \mu \mathrm{m}$, reaction time was 3 hours, oxygen flow was from 1 liter per min to 2.5 liter per min (different for each value of oxygen pressure), agitation speed was $700 \mathrm{rpm}$, and Thar lignite coal to solution ratio was 50 grams of coal to $500 \mathrm{ml}$ of $\mathrm{NaOH}$ solution.

It was investigated that the higher the value of oxygen partial pressure, lower the value of sulfur in processed coal (higher rate of desulfurization). Although the pyritic sulfur reduction was higher than that of organic sulfur and sulfate sulfur. The behavior of sulfur reduction with respect to the oxygen partial pressure was uniform as shown in figure 10 . About $88 \%$ pyritic sulfur was removed at 200 psi partial 
pressure of oxygen, organic sulfur reduction was achieved up to $74 \%$, while sulfate sulfur removal was about $50 \%$ and around $79.8 \%$ of total sulfur was removed at that pressure as shown in figure 9 .

The related behavior was observed by Chaung (Taylor, n.d.), that when the oxygen partial pressure was raised the conversion rate of pyrite to hematite was also increased. He leached the iron pyrite (of Lova state) with sodium carbonate in dissolved oxygen (and also with water and dissolved oxygen) he found more than $75 \%$ sulfur from pyrite was removed. He concluded that the rate of desulfurization of pyrite depends up on the overall rate of diffusion of dissolved oxygen. This study also showed temperature effect at two different oxygen partial pressures indicated that more organic sulfur was removed at the higher oxygen partial pressure than that at the lower oxygen partial pressure. These results suggested that oxygen partial pressure has an important effect on the removal of both organic and inorganic sulfur.

The agitation speed has also great influence on the desulfurization. To study the effect of agitation speed Thar coal was leached with 0.25 Molarity of $\mathrm{NaOH}$, leaching time was 3 hours and oxygen partial pressure was $100 \mathrm{psi}$, the oxygen flow rate was 1.2 liters per minute, leaching temperature was $120^{\circ} \mathrm{C}$, ratio of raw Thar coal to $\mathrm{NaOH}$ was $50 \mathrm{grams}$ in $500 \mathrm{ml}$ of solution and particle size was $40 \mu \mathrm{m}$, the speed of agitation was different for each experiment ranged from $150 \mathrm{rpm}$ to $2000 \mathrm{rpm}$. At $2000 \mathrm{rpm}$ the pyritic sulfur reduction was achieved about $78.8 \%$ and sulfate sulfur reduction was about $60 \%$ while organic sulfur reduction was observed as $58 \%$ and total sulfur reduction was achieved up to $70 \%$ as shown in figure 12.

It was observed that with increase in agitation speed from $150 \mathrm{rpm}$ to $1500 \mathrm{rpm}$ the rate of desulfurization was also increased and above $1500 \mathrm{rpm}$ it became constant and did not change as shown in figure 11. Hence 1500rpm was found to be an optimum speed of agitation. Sulfur reduced slightly in organic as well as in sulfate sulfur, while in pyritic sulfur, great sulfur reduction was observed. Ali Ahmed (Ahmed et al. 2008) leached the Lakhra coal with Hydrogen peroxide $\left(\mathrm{H}_{2} \mathrm{O}_{2}\right)$ and nitric acid was used as Oxidative agents for desulfurization of coal, he investigated that desulfurization of coal was increased with increase in rate of agitation. K Chuang (Chuang, Markuszewski, and Wheelock 1983) treated the American coal with dilute sodium carbonate solution in dissolved oxygen under pressure, he studied the effect of agitation on desulfurization rate, he observed that coal desulfurization was increased rapidly with increase in agitation.

\section{Optimize Reaction}

After getting the optimum value of each factor an optimize reaction was performed to get the practical optimized value of sulfur removal from Thar coal, in this reaction the temperature was $120^{\circ} \mathrm{C}$, partial pressure of oxygen was 200 psi, reaction time was 4 hours, particle size was $4 \mu \mathrm{m}$ and agitation speed was $1500 \mathrm{rpm}$. After lab analysis of product coal, pyrite sulfur reduction was achieved up to $90.3 \%$ $(0.17 \%$ pyrite was left in processed coal), and organic sulfur was removed up to $78 \%(0.11 \%$ organic sulfur left in processed coal) and sulfate sulfur removal was up to $50 \%$, while total sulfur removal was achieved up to $82 \%$, and the processed coal contained only $0.83 \%$ total sulfur. This data shows that 
oxidative alkali leaching is very effective for the pyritic sulfur removal as well as for organic sulfur removal and amount of sulfate sulfur was also reduced to half.

\section{TGA of raw coal and processed coal}

Desulfurization of coal effects on the combustion behavior of coal (Ken et al. 2018), thermogravimetric test is well known technique to identify the various important changes in combustion of coal owing to coal desulfurization (Gundogar and Kok 2014), TGA gives the mass of fuel changes during combustion as a function of time, to study this variation the raw coal and processed samples were characterized by TGA test as shown in figure 13.

A raw coal and three processed samples were selected for this study. Sample 1 was coal that was treated at optimum temperature $120^{\circ} \mathrm{C}$ for three hours, having the composition as; pyrite sulfur $0.34 \%$, sulfate sulfur $0.14 \%$, organic sulfur $0.17 \%$, and total sulfur $0.65 \%$. Sample 2 was processed coal that was treated at optimum pressure of 200 psi, its composition was; pyrite sulfur $0.21 \%$, sulfate sulfur $0.1 \%$, organic sulfur $0.13 \%$ while total sulfur was $0.44 \%$. And sample 3 was the processed coal that was treated under optimized conditions with composition as; pyrite $0.17 \%$, sulfate sulfur $0.1 \%$, organic sulfur $0.11 \%$ and total sulfur $0.38 \%$.

It was observed that in raw Thar lignite coal a little amount of mass loss was observed up to the temperature of $150^{\circ} \mathrm{C}$, this mass loss was due to the decomposition of light volatile matters, as observed by Kulnil (Cong et al. 2019) and then shows the static behavior (no slope in TGA graph) of coal till the temperature reached $400^{\circ} \mathrm{C}$, that showed the thermal stability (Sikarwar et al. 2018)(Marinov et al. 2010) of Thar lignite till $380^{\circ} \mathrm{C}$. After $380^{\circ} \mathrm{C}$ mass of coal was rapidly reduced, about $75 \%$ coal mass lost as the temperature was further raised about $300^{\circ} \mathrm{C}$ (up to $680^{\circ} \mathrm{C}$ ), this was owing to rapid combustion of coal between $380^{\circ} \mathrm{C}$ to $680^{\circ} \mathrm{C}$, this mass loss was due to release of volatile matter and burning of coal and this demonstrate coal combustion region or primary reaction region in TGA test as reported by Kok (Ozbas, Kök, and Hicyilmaz 2002). Hence the peak combustion temperature of Thar lignite was $380^{\circ} \mathrm{C}$, after that temperature the Thar coal started to degrade. While in processed coal loss of mass with rise in temperature was smooth as compared to raw coal. Kok and Hicyilmaz observed that coal leaching showed the significant effect on the coal combustion, they studied the raw and cleaned coal by TGA characterization and found that the coal leaching reduced the peak combustion temperature and showed the smooth mass reduction with the temperature increase. The similar behavior was observed by Bhupendra (Ken et al. 2018) while examining the TGA analysis of raw Indian coal and processed coal with $\mathrm{KOH}$ of various concentrations, he observed that coal mass was rapidly lost from temperature $330^{\circ} \mathrm{C}$ to $520^{\circ} \mathrm{C}$, while coal samples that were processed with $\mathrm{KOH}$ for longer time showed some uniformity of mass loss per temperature rise.

\section{Testo smoke number}


The raw coal and treated coal were characterized with testo smoke number to study the difference in combustion smoke of raw coal and two samples of treated coal. Sample 1 was treated at optimum pressure of 200psi with composition as; pyrite sulfur $0.21 \%$, sulfate sulfur $0.1 \%$, organic sulfur $0.13 \%$ and total sulfur $0.44 \%$. And sample 2 was treated under optimum condition, its composition was; pyrite $0.17 \%$, sulfate sulfur $0.1 \%$, organic sulfur $0.11 \%$ and total sulfur $0.38 \%$.

The Thar coal was characterized with testo smoke number. Initially the smoke number of raw Thar coal was 2 , but after 5 minutes it became 6 , and after 10 minutes smoke of raw coal was totally black and was measured as 9 on testo smoke number, hence it reached the highest number of coal smoke.

Similarly, the testo smoke number of processed coals was also observed, initially the testo smoke number of sample was 1 after five minutes the smoke number became 4 and after ten minutes the smoke number was reduced to 3 and the sample was very clean than that of raw Thar coal. Sample 2 also showed similar results initially but after five minutes the smoke number was 5 and then after ten minutes it became 3 . So the testo smoke number showed that smoke property of processed coal was enhanced and the coal become environmental friendly.

\section{Conclusion}

Desulfurization of coal by alkali oxidative leaching under pressure was found to be very effective, about $90.3 \%$ pyritic sulfur was removed and other sulfur contaminations types present in coal as organic sulfur was removed up to $78 \%$ and sulfate sulfur was removed $50 \%$ and total sulfur removal was up to $82.5 \%$. Hence a sufficient amount of sulfur reduction was achieved.

As the reaction starts pyrite reacts with water and oxygen to form the hematite and sulfuric acid, this sulfuric acid immediately neutralizes with sodium hydroxide $(\mathrm{NaOH})$ and forms sodium sulfate precipitate (noncombustible sulfur) and water molecules. Oxygen plays an important role in chemical reaction, and is responsible to convert the pyrite to hematite, owing to this maximum amount of pyritic sulfur and total sulfur was removed at higher amount of oxygen partial pressure. While studying the effect of various factors individually, almost in every case pyritic sulfur was removed in greater amount than that of sulfate or organic sulfur.

Desulfurization was maximum at higher values of reaction time, partial pressure of oxygen and agitation speed. The value for partial pressure for maximum desulfurization was found to be 200psi, reaction time 4 hours at agitation speed of $1500 \mathrm{rpm}$. Although desulfurization was observed to be greater with smaller particle size. Optimum value for $\mathrm{NaOH}$ concentration was 0.25 Molarity and that of temperature was $120^{\circ} \mathrm{C}$.

Thermogravimetric and smoke properties of processed coal were also improved.

\section{Declarations}




\section{Conflict of interest}

Authors declare that there is no conflict of interest with editor and with the reviewer.

\section{Acknowledgment}

Authors thanks to chemical department Dawood University of Engineering and technology karachi and Fuel research centre, karachi.

\section{References}

Ahmad, Waqas, Imtiaz Ahmad, Rashid Ahmad, Zakir Ullah, and Muhammad Ibrahim. (2019) Desulfurization of Lakhra Coal by Combined Leaching and Catalytic Oxidation Techniques. International Journal of Coal Preparation and Utilization 0 (0): 1-17.

https://doi.org/10.1080/19392699.2019.1583648.

Ahmed, Ali, Naseer Ahmad, Rizwan Shah, M Naeem Bhatti, and Mahmood Saleem. (2008) Coal Desulfurization by Solvent Leaching Methods. Journal of Faculty of Engineering \& Technology, no. December: 47-56.

Andersen, J. E., J. Halpern, and C. S. Samis. (1953). Kinetics of the Oxidation of Galena in Sodium Hydroxide Solutions Under Oxygen Pressure. Jom 5 (4): 554-58. https://doi.org/10.1007/bf03397517.

Anwar, Fraz, Rizwan Nasir, Khuram Maqsood, Humbul Suleman, Faisal Rehman, Abulhassan Ali, Aymn Abdulrahman, Anas Ahmad, and Abdullah Bin Mahfouz. (2020) Desulfurization and Optimization of LowGrade Local Coal by Sequential KOH and HCl Treatment. Journal of Sulfur Chemistry 41 (1): 44-56. https://doi.org/10.1080/17415993.2019.1662907.

Benassi, Rois, Luca G Fiandri, and Ferdinando Taddei. (1997) Ab-Initio MO Study of the Peracid Oxidation of Dimethyl Thiosulfinate 3263 (9): 8018-23.

Chiri, Paul, and Michel L Schlegel. (2017) Pyrite Oxidation in Air-Equilibrated Solutions: An Electrochemical Study 470 (August): 67-74. https://doi.org/10.1016/j.chemgeo.2017.08.023.

Chuang, K. C., R. Markuszewski, and T. D. Wheelock. (1983) Desulfurization of Coal by Oxidation in Alkaline Solutions Fuel Processing Technology 7 (1): 43-57. https://doi.org/10.1016/03783820(83)90024-3.

Cong, Kunlin, Feng Han, Yanguo Zhang, and Qinghai Li. (2019) The Investigation of Co-Combustion Characteristics of Tobacco Stalk and Low Rank Coal Using a Macro-TGA. Fuel 237 (June 2018): 126-32. https://doi.org/10.1016/j.fuel.2018.09.149. 
Franco, Alessandro, and Ana R. Diaz. (2009) The Future Challenges for 'Clean Coal Technologies': Joining Efficiency Increase and Pollutant Emission Control. Energy 34 (3): 348-54.

https://doi.org/10.1016/j.energy.2008.09.012.

Gundogar, Asli S., and Mustafa V. Kok. (2014). Thermal Characterization, Combustion and Kinetics of Different Origin Crude Oils. Fuel 123: 59-65. https://doi.org/10.1016/j.fuel.2014.01.058.

Gürü, M., B. V. Sariöz, and Ç Çakanyildirim. (2008) Oxidative Desulfurization of Tufanbeyli Coal by Hydrogen Peroxide Solution. Energy Sources, Part A: Recovery, Utilization and Environmental Effects 30 (11): 981-87. https://doi.org/10.1080/00908310600714006.

Kara, Hüsein, and Ramazan Ceylan. (1988) Removal of Sulphur from Four Central Anatolian Lignites by $\mathrm{NaOH}$. Fuel 67 (2): 170-72. https://doi.org/10.1016/0016-2361(88)90258-X.

Karaca, Semra, and Muammer Akyu. (2003) The Removal of Pyritic Sulfur from As B Kale Lignite in Aqueous Suspension by Nitric Acid .80: 1-8.

Ken, Bhupendra Singh, Subhajit Aich, V. K. Saxena, and Barun Kumar Nandi. (2018) Combustion Behavior of KOH Desulphurized Coals Assessed by TGA-DTG. Energy Sources, Part A: Recovery, Utilization and Environmental Effects 40 (20): 2458-66. https://doi.org/10.1080/15567036.2018.1502844.

Kozłowski, M., H. Wachowska, and J. Yperman. (2003) Transformations of Sulphur Compounds in HighSulphur Coals during Reduction in the Potassium/Liquid Ammonia System. Fuel 82 (9): 1149-53. https://doi.org/10.1016/S0016-2361(03)00005-X.

Li, Zhiling, Tonghua Sun, and Jinping Jia. (2010) An Extremely Rapid, Convenient and Mild Coal Desulfurization New Process: Sodium Borohydride Reduction. Fuel Processing Technology 91 (9): 116267. https://doi.org/10.1016/j.fuproc.2010.03.031.

Liu, Kaicheng, Ji Yang, Jinping Jia, and Yaling Wang (2008) Desulphurization of Coal via Low Temperature Atmospheric Alkaline Oxidation." Chemosphere 71 (1): 183-88. https://doi.org/10.1016/j.chemosphere.2007.10.005.

Malkani, M. Sadiq. (2012) A Review of Coal and Water Resources of Pakistan. Science, Technology and Development 31 (3): 202-18. https://www.researchgate.net/publication/282355331.

Malkani, M Sadiq, and Zafar Mahmood Malik. (2018). Coal Resources of Pakistan: Entry of New Coalfields Government of Pakistan Ministry of Petroleum \& Natural Resource Geological Survey of Pakistan Information Release No . 980 . Coal Resources of Pakistan: Entry of New Coalfields By Zafar Mahmood Issued, no. January 2017.

Marinov, S P, L Gonsalvesh, M Stefanova, J Yperman, R Carleer, G Reggers, Y Yürüm, V Groudeva, and P Gadjanov. (2010) Thermochimica Acta Combustion Behaviour of Some Biodesulphurized Coals Assessed by TGA / DTA. 497: 46-51. https://doi.org/10.1016/j.tca.2009.08.012. 
Meshram, Pratima, B. K. Purohit, M. K. Sinha, S. K. Sahu, and B. D. Pandey. (2015). Demineralization of Low Grade Coal - A Review. Renewable and Sustainable Energy Reviews 41: 745-61.

https://doi.org/10.1016/j.rser.2014.08.072.

Mketo, Nomvano, Philiswa Nosizo Nomngongo, and Jane Catherine Ngila. (2017). Rapid Total Sulphur Reduction in Coal Samples Using Various Dilute Alkaline Leaching Reagents under Microwave Heating: Preventing Sulphur Emissions during Coal Processing. Environmental Science and Pollution Research 24 (24): 19852-58. https://doi.org/10.1007/s11356-017-9632-y.

Mukherjee, S., and P. C. Borthakur.( 2001) Chemical Demineralization/Desulphurization of High Sulphur Coal Using Sodium Hydroxide and Acid Solutions. Fuel 80 (14): 2037-40.

https://doi.org/10.1016/S0016-2361(01)00094-1.

Mukherjee, Samit, and P. C. Borthakur.( 2004) Effects of Alkali Treatment on Ash and Sulphur Removal from Assam Coal. Fuel Processing Technology 85 (2-3): 93-101. https://doi.org/10.1016/S03783820(03)00139-5.

Mukherjee, Samit, and Prakash Chandra Borthakur. (2003)E ffect of Leaching High Sulphur Subbituminous Coal by Potassium Hydroxide and Acid on Removal of Mineral Matter and Sulphur. Fuel 82 (7): 783-88. https://doi.org/10.1016/S0016-2361(02)00360-5.

Munir, Mehr Ahmed Mujtaba, Guijian Liu, Balal Yousaf, Muhammad Ubaid Ali, and Qumber Abbas. (2018 )Enrichment and Distribution of Trace Elements in Padhrar, Thar and Kotli Coals from Pakistan:

Comparison to Coals from China with an Emphasis on the Elements Distribution.Journal of Geochemical Exploration 185 (November 2017): 153-69. https://doi.org/10.1016/j.gexplo.2017.11.009.

Mursito, Anggoro Tri, Tsuyoshi Hirajima, and Keiko Sasaki. (2011) Alkaline Hydrothermal De-Ashing and Desulfurization of Low Quality Coal and Its Application to Hydrogen-Rich Gas Generation. Energy Conversion and Management 52 (1): 762-69. https://doi.org/10.1016/j.enconman.2010.08.001.

Nowak, Michael A., Bruce R. Utz, Daniel J. Fauth, Sidney Friedman, James P. Knoer, and Nancy Gessner ( 1989) Decomposition of Coal Model Compounds During Simulated Chemical Coal Cleaning with Molten Hydroxides." Coal Preparation 7 (1-2): 29-36. https://doi.org/10.1080/07349348908960539.

Ozbas, K E, M V Kök, and C Hicyilmaz. (2002) COMPARATIVE KINETIC ANALYSIS OF RAW AND CLEANED COALS .69: 541-49.

Prasassarakich, Pattarapan, and Thitima Thaweesri. (1996) Kinetics of Coal Desulfurization with Sodium Benzoxide. Fuel 75 (7): 816-20. https://doi.org/10.1016/0016-2361(96)00025-7.

Rehman, Faisal, Syed Waqas Ahmad, M. Shahzad Zafar, Sajjad Ahmad, and Muhammad Zia-Ul-Haq.( 2018) Parametric Optimization of Coal Desulfurization Through Alkaline Leaching. Polish Journal of Chemical Technology 20 (3): 103-9. https://doi.org/10.2478/pjct-2018-0045. 
Saikia, Binoy K., Kakoli Khound, and Bimala P. Baruah. (2014) Extractive De-Sulfurization and de-Ashing of High Sulfur Coals by Oxidation with lonic Liquids. Energy Conversion and Management 81: 298-305. https://doi.org/10.1016/j.enconman.2014.02.043.

Sharma, D. K., and Sanjay Gihar. (1991)Chemical Cleaning of Low Grade Coals through Alkali-Acid Leaching Employing Mild Conditions under Ambient Pressure. Fuel 70 (5): 663-65.

https://doi.org/10.1016/0016-2361(91)90182-A.

Sikarwar, Prerana, U K Arun Kumar, Vijayalakshmi Gosu, and V Subbaramaiah. (2018) Graphical Abstract SC. Biochemical Pharmacology. https://doi.org/10.1016/j.jece.2018.02.021.

TAI, C. Y., G. V. GRAVES, and T. D. WHEELOCK. (1977) Desulfurizing Coal with Alkaline Solutions Containing Dissolved Oxygen. 182-97. https://doi.org/10.1021/bk-1977-0064.ch015.

Taylor, Publisher. (2014)PYRITE DESULFURIZATION BY WET OXIDATION IN ALKALINE SOLUTIONS PY: RITE DESULFURIZATION BY WET OXI: DATION IN ALKALINE SOLUTIONS," no. October 2014: 37-41. https://doi.org/10.1080/00986448008912550.

Utz, Bruce R., Sidney Friedman, and Steven K. Soboczenski. (1986)Molten Hydroxide Coal Desulfurization Using Model Systems. 51-62. https://doi.org/10.1021/bk-1986-0319.ch005.

Wheelock, T. D. (1981)Oxydesulfurization of Coal in Alkaline Solutions. Chemical Engineering Communications 12 (1-3): 137-59. https://doi.org/10.1080/00986448108910834.

Xia, Wencheng, and Guangyuan Xie. (2017)A Technological Review of Developments in Chemical-Related Desulfurization of Coal in the Past Decade." International Journal of Mineral Processing 161: 65-71. https://doi.org/10.1016/j.minpro.2017.02.013.

Струков, Б.А., and А.П. Леванюк. 1983. “No ТitlеФизические Основы Сегнетоэлектрических Явлений в Кристаллах" 7: 240.

Waugh A, and Blowing K. 1984. "Removal of mineral matter from bituminous coals by aqueous chemical leaching" marine Science Bulletin 9: 217-33.

\section{Figures}




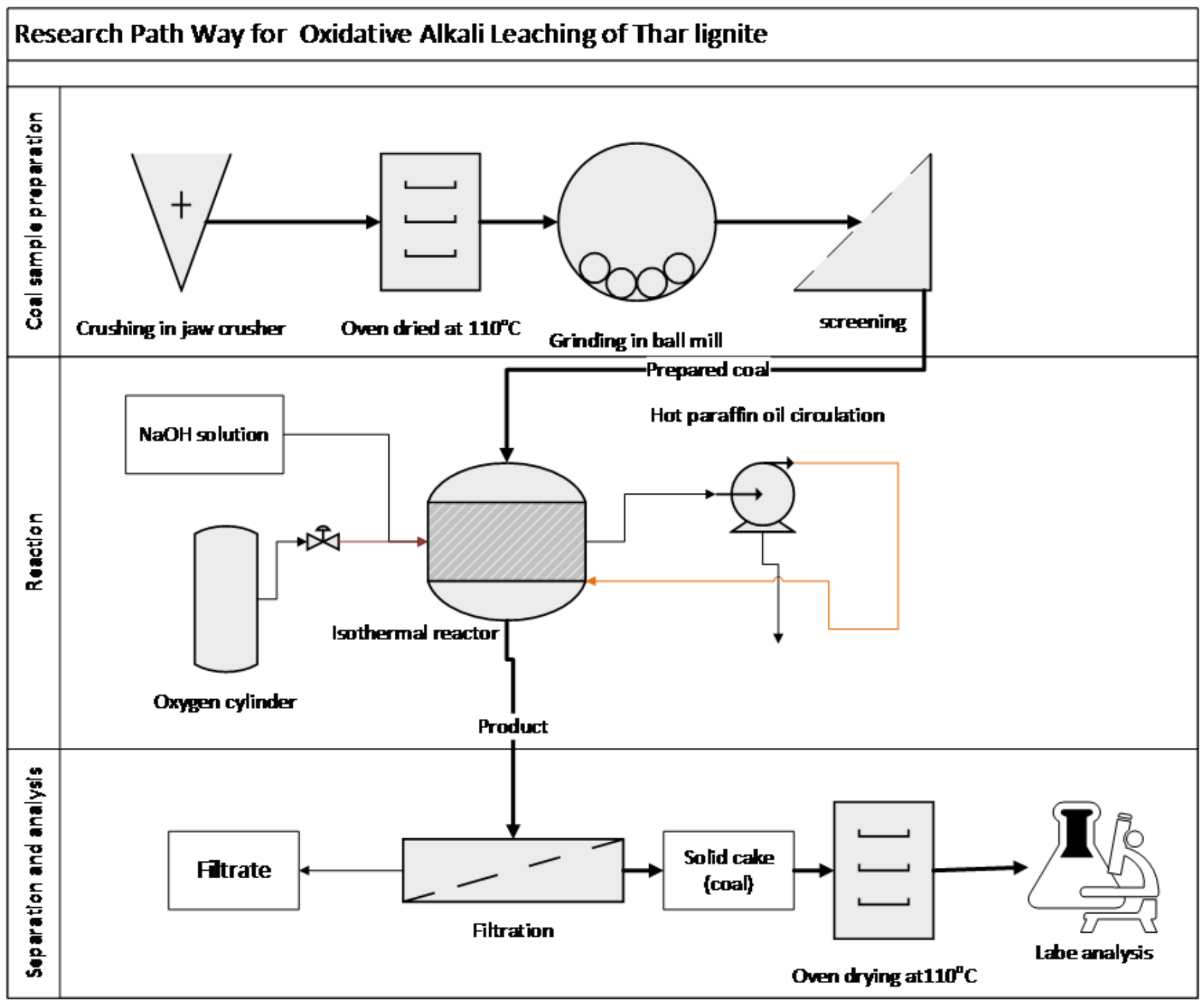

Figure 1

Flow diagram of alkali oxidative leaching of Thar coal 

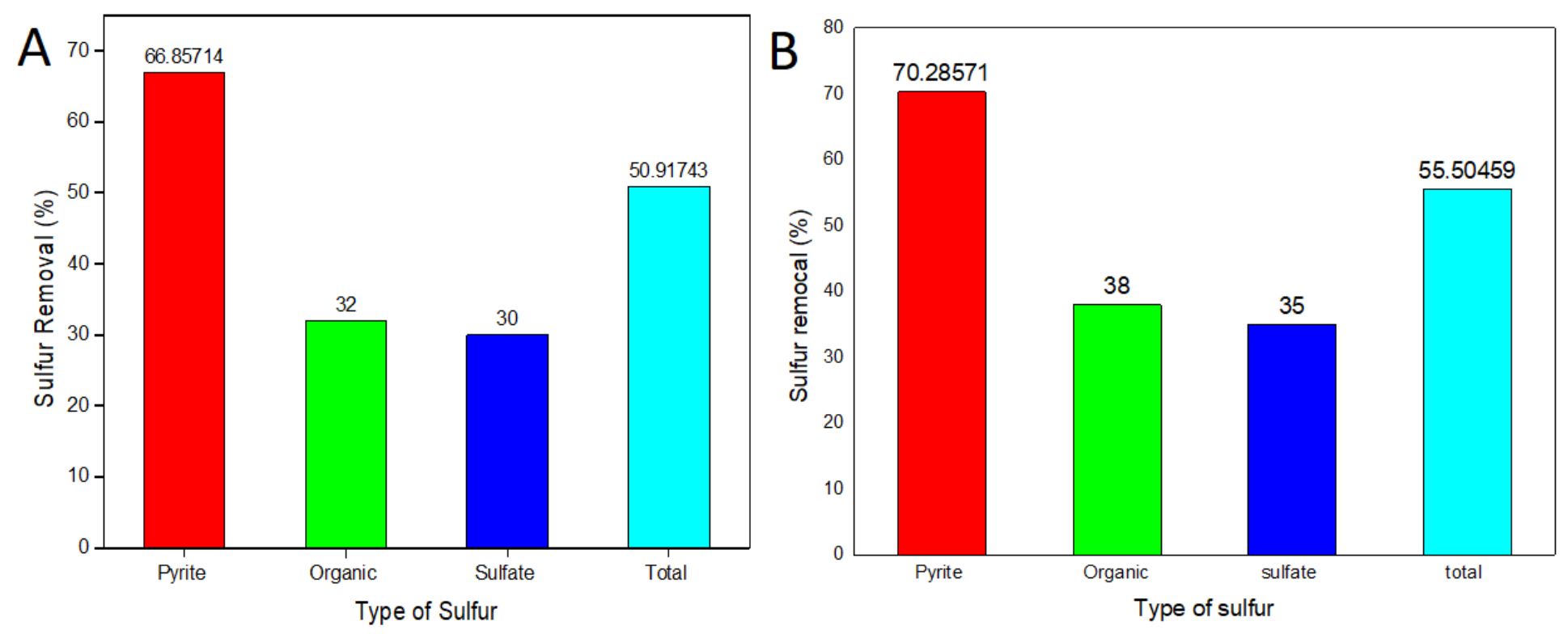

Figure 2

(a) Sulfur removal \% from Thar lignite coal at $2.5 \mathrm{Molarity}$ of $\mathrm{NaOH}$, temperature at $120 \mathrm{oC}$, Oxygen partial pressure 50psi, leaching time 1.5 hours (b) Sulfur removal \% from Thar lignite coal at 2.5 Molarity of $\mathrm{NaOH}$, at $120 \mathrm{oC}$, Oxygen partial pressure 100psi, leaching time 1.5 hours
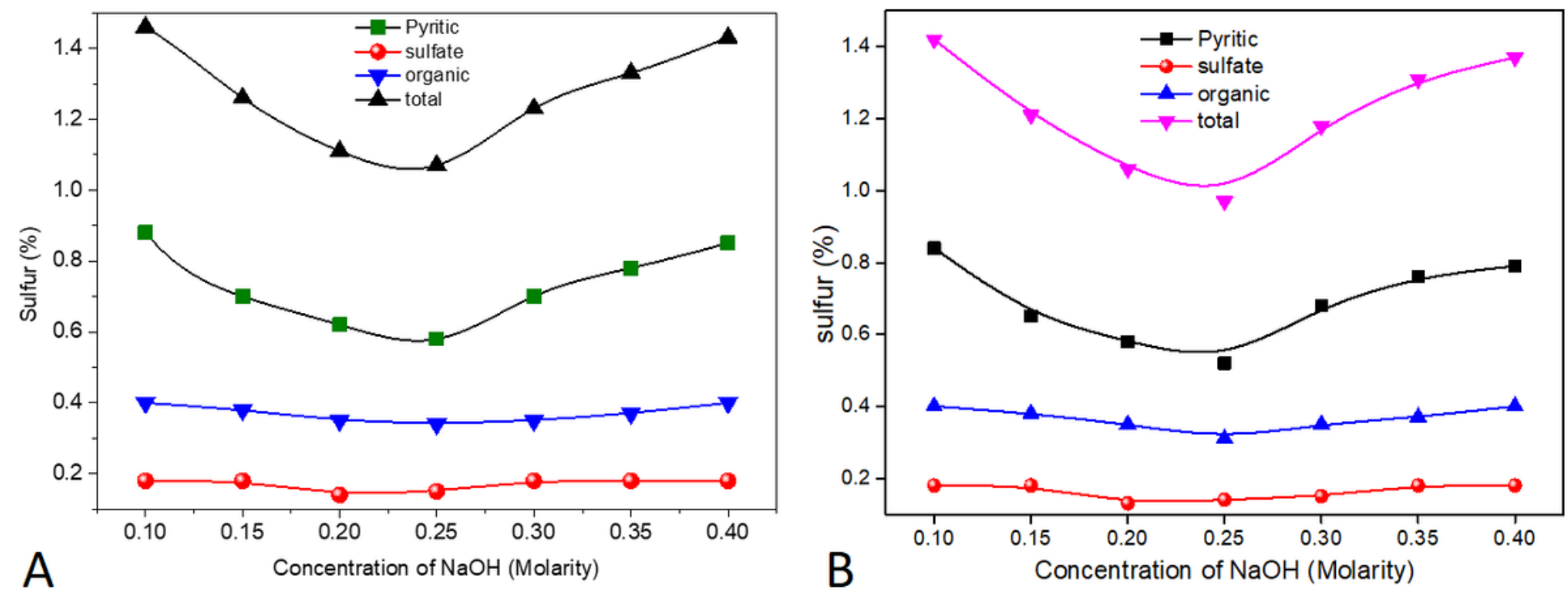

Figure 3

(a) Effect of concentration on Sulfur removal at partial pressure of oxygen 50psi, temperature $120 \mathrm{oC}$,

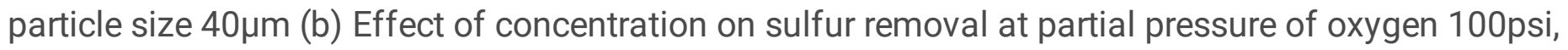
temperature $120 \mathrm{oC}$, particle size $40 \mu \mathrm{m}$ 

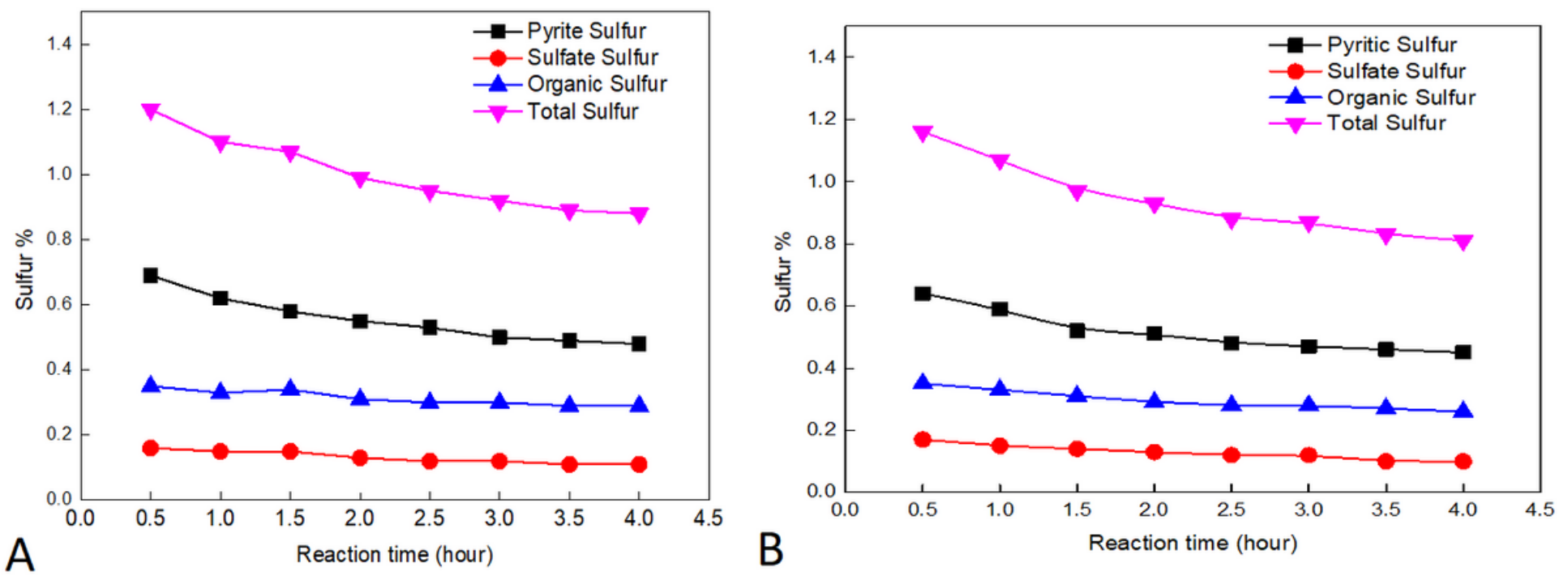

Figure 4

(a) Effect of reaction time on desulfurization, at partial pressure of oxygen $50 \mathrm{psi}$, particle size $40 \mu, \mathrm{NaOH}$ concentration 0.25 Molarity, temperature $120^{\circ} \mathrm{C}$ and at $500 \mathrm{grams}$ in $50 \mathrm{ml}$ solution of $\mathrm{NaOH}$ (b) Effect of reaction time on desulfurization, at partial pressure of oxygen 100psi, particle size $40 \mu, \mathrm{NaOH}$ concentration $0.25 \mathrm{Molarity}$, temperature $120^{\circ} \mathrm{C}$ and at $500 \mathrm{grams}$ in $50 \mathrm{ml}$ solution of $\mathrm{NaOH}$.

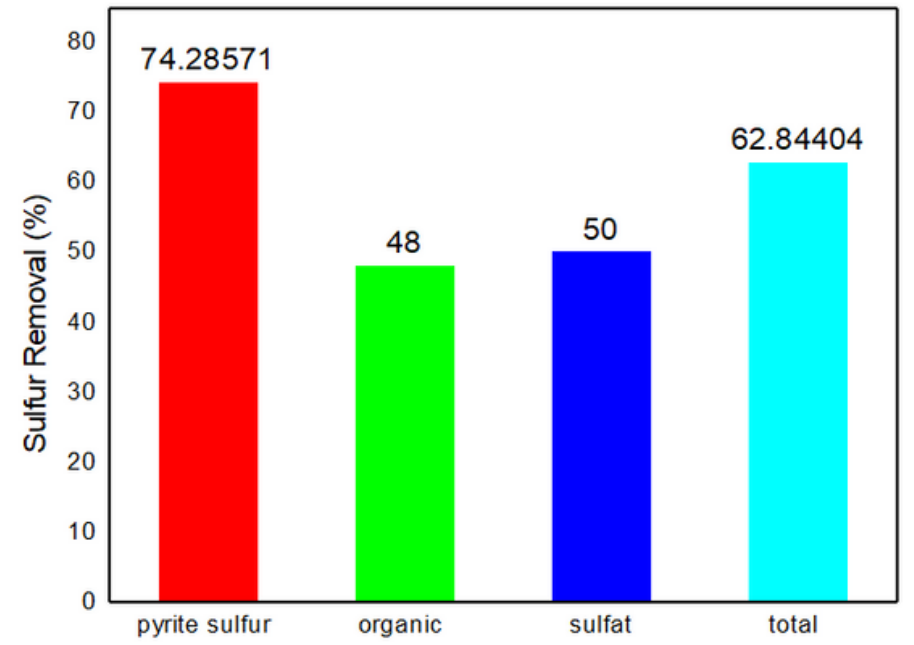

A

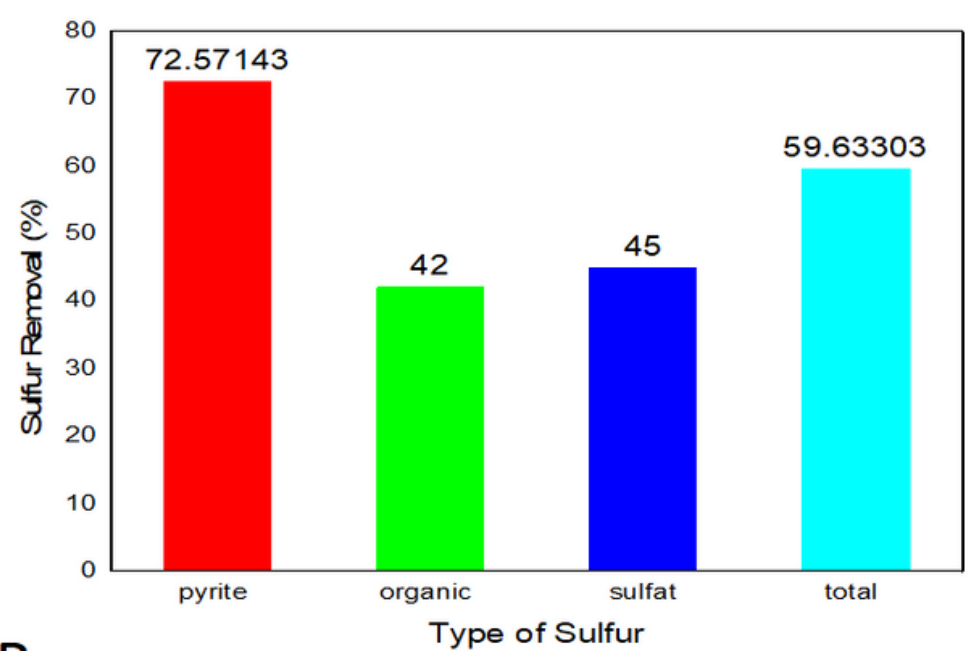

B

Figure 5

(a) Sulfur removal \% at maximum reaction time 4-hour, partial pressure of oxygen 100psi, particle size $40 \mu, \mathrm{NaOH}$ concentration 0.25 Molarity, temperature $120 \mathrm{oC}$. (b) Sulfur removal $\%$ at maximum reaction time 4-hour, partial pressure of oxygen 50psi, particle size $40 \mu \mathrm{m}, \mathrm{NaOH}$ concentration 0.25 Molarity, temperature $120 \mathrm{oC}$. 


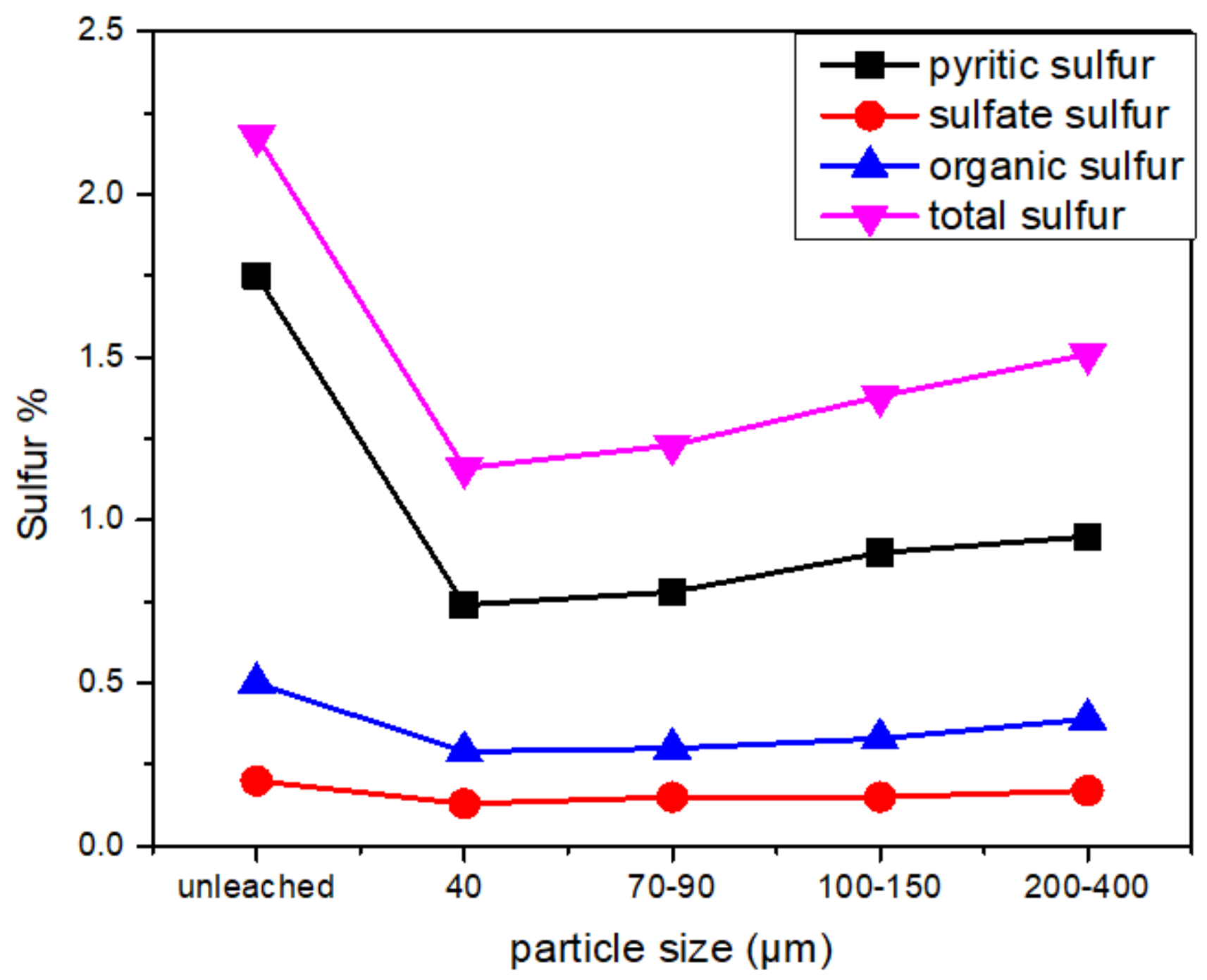

Figure 6

Effect of particle size on desulfurization of Thar coal at partial pressure of oxygen $100 \mathrm{psi}, \mathrm{NaOH}$ concentration 0.2 Molarity, temperature $120 \mathrm{oC}$ and coal to solution ratio $50 \mathrm{grams}$ in $500 \mathrm{ml}$ solution of $\mathrm{NaOH}$, reaction time was 2 hours 

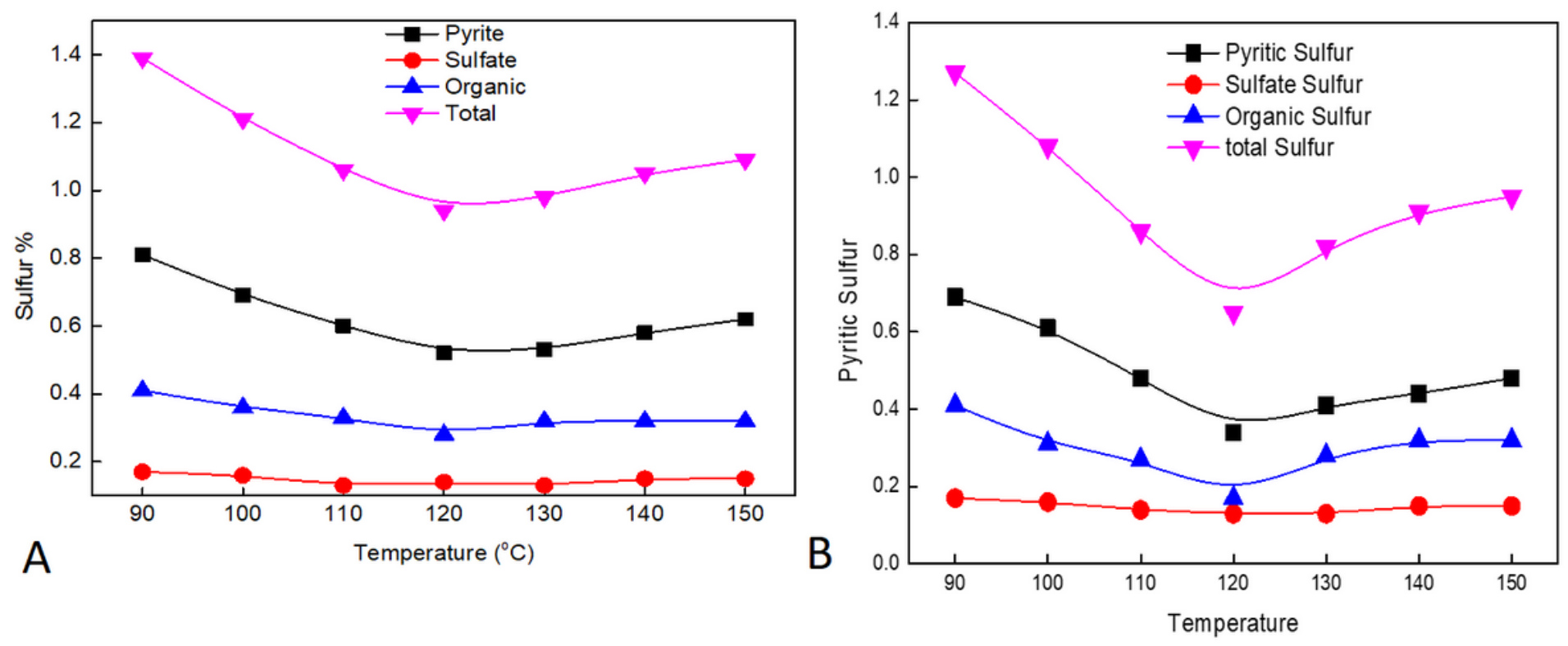

Figure 7

(a) Effect of temperature on desulfurization of Thar coal at partial pressure of oxygen $100 \mathrm{psi}, \mathrm{NaOH}$ concentration of 0.2 Molarity, agitation speed $700 \mathrm{rpm}$, flow rate of oxygen 1.2 liter per minute, particle size $4 \mu \mathrm{m}$, coal to solution ratio was $500 \mathrm{grams}$ in $50 \mathrm{ml}$ of solution of $\mathrm{NaOH}$, reaction time was 1.5 hours. (b) Effect of temperature on desulfurization of Thar coal at partial pressure of oxygen $100 \mathrm{psi}, \mathrm{NaOH}$ concentration of 0.2 Molarity, agitation speed $700 \mathrm{rpm}$, particle size $4 \mu \mathrm{m}$, reaction time was 3 hours.
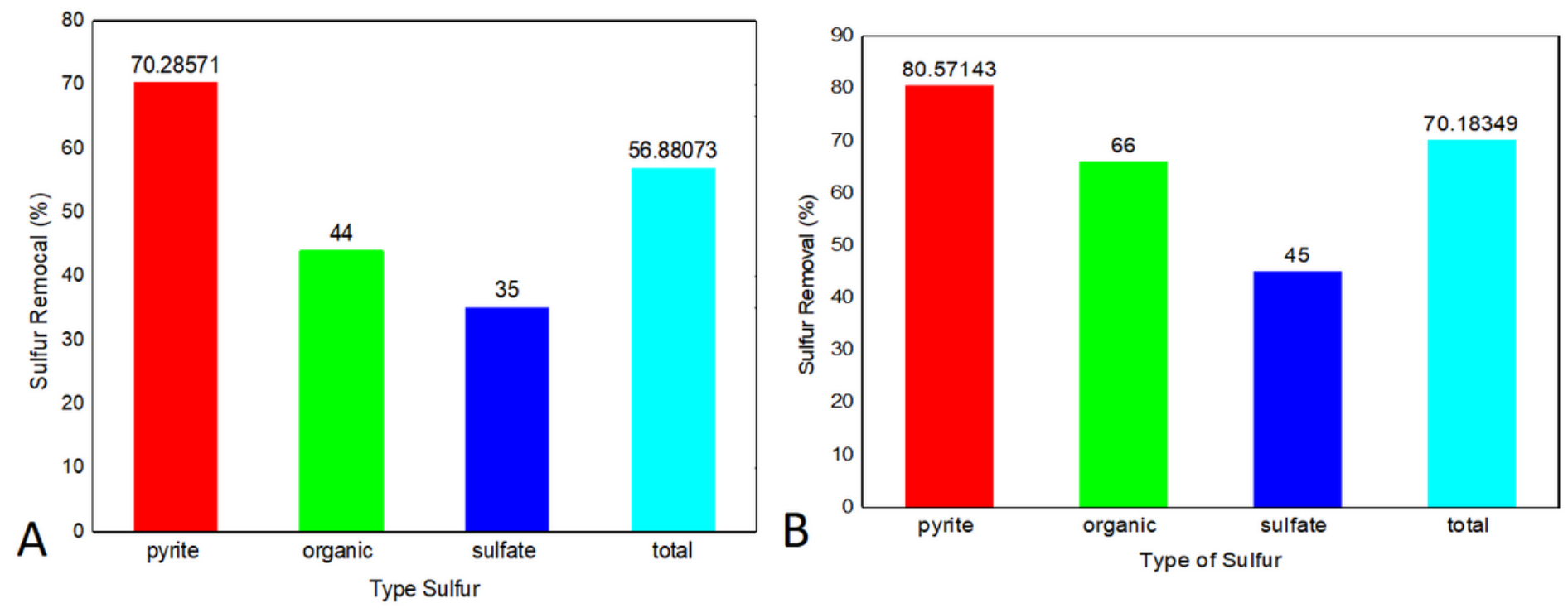

Figure 8

(a) Sulfur removal \% at optimum reaction temperature of $120 \mathrm{oC}$, partial pressure of oxygen 100psi, particle size $40 \mu \mathrm{m}, \mathrm{NaOH}$ concentration 0.2 Molarity and reaction time 1.5 hours. (b) Sulfur removal \% at optimum reaction temperature of $120 \mathrm{oC}$, partial pressure of oxygen $100 \mathrm{psi}$, particle size $40 \mu \mathrm{m}, \mathrm{NaOH}$ concentration 0.2 Molarity and reaction time 3hours. 


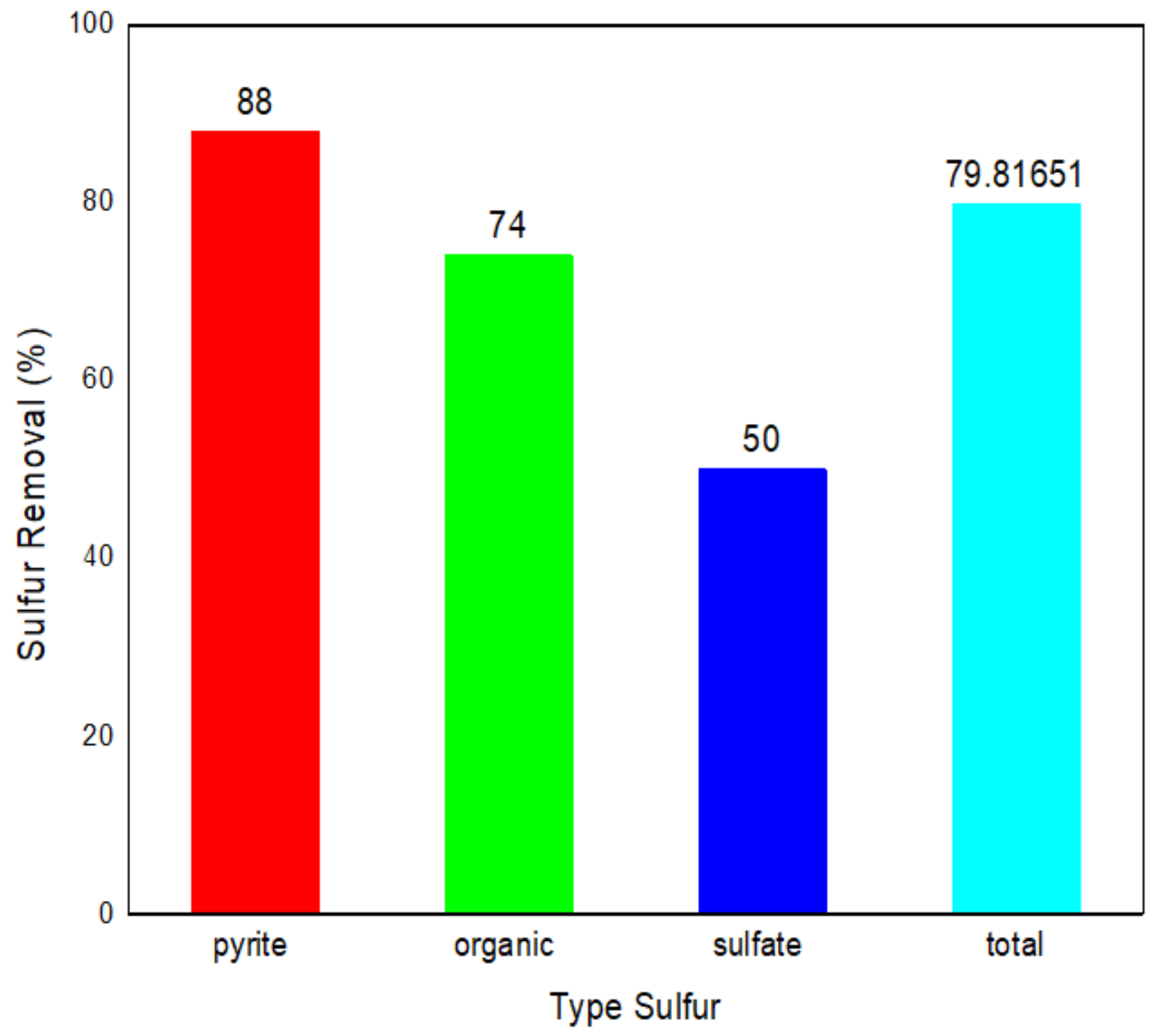

Figure 9

Sulfur removal \% at maximum partial pressure of oxygen of 200psi, particle size $40 \mu \mathrm{m}, \mathrm{NaOH}$ concentration 0.25 Molarity and reaction time 3hours, temperature of $120 \mathrm{oC}$, reaction time 3 hours 


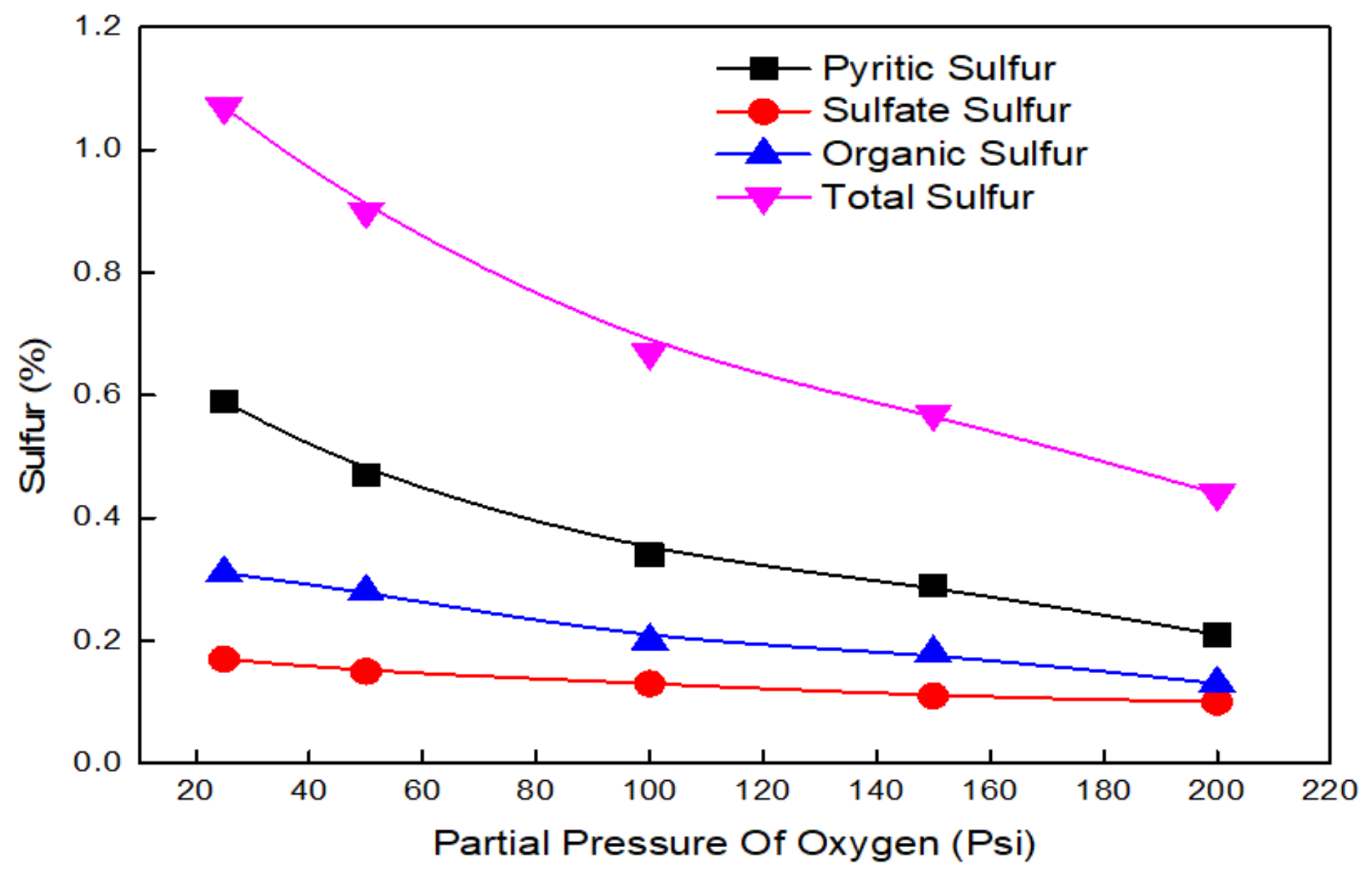

Figure 10

Effect of oxygen partial pressure with $\mathrm{NaOH}$ concentration 0.2 Molarity, particle size $4 \mu \mathrm{m}$, reaction time 3 hours, reaction temperature $120 \mathrm{oC}$ 


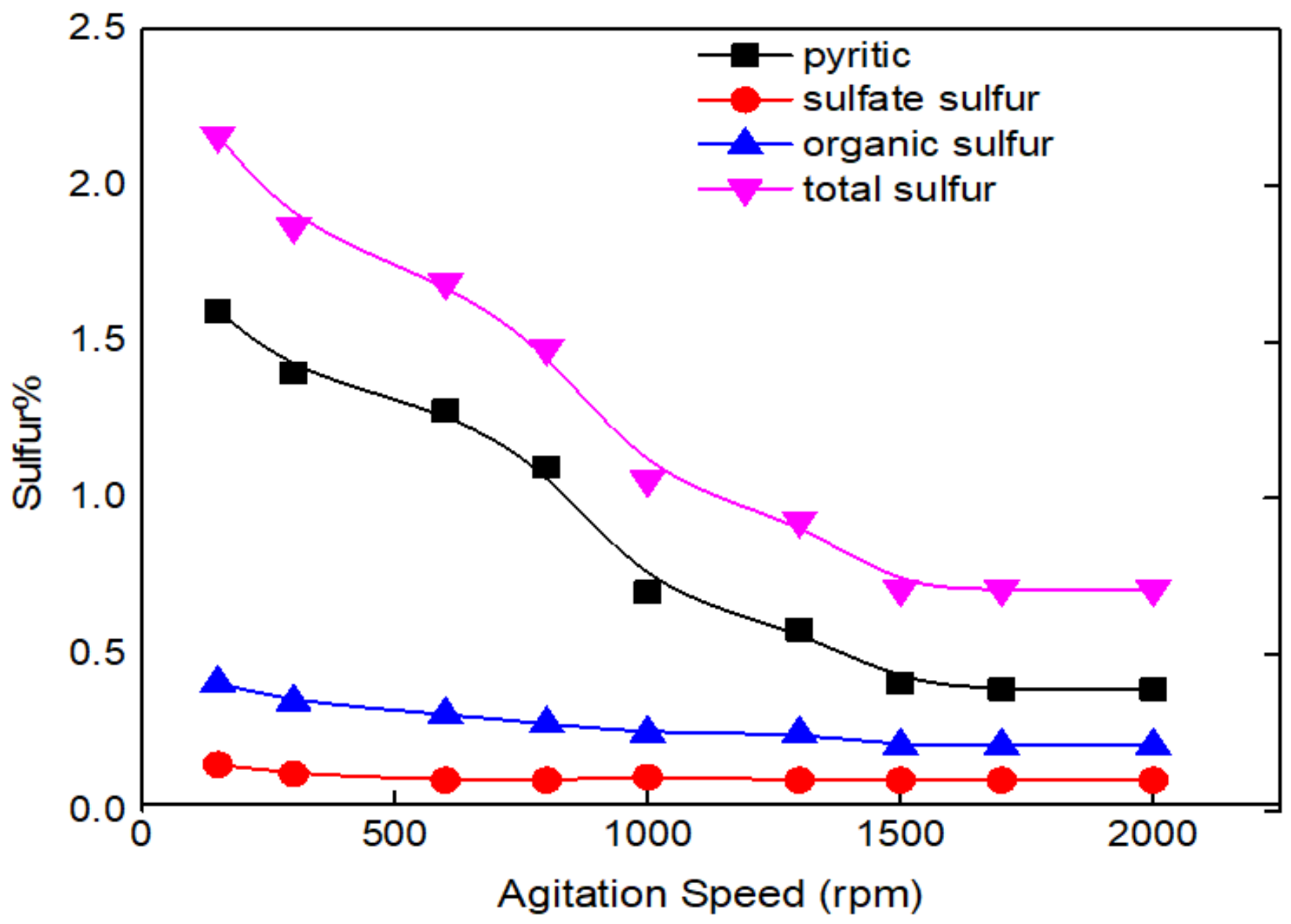

Figure 11

Effect of agitation speed on desulfurization of Thar coal at $\mathrm{NaOH}$ concentration $0.2 \mathrm{Molarity}$, particle size $4 \mu \mathrm{m}$, coal to solution ratio 50 grams in $500 \mathrm{ml}$ solution of $\mathrm{NaOH}$, reaction time 3 hours, leaching temperature $120 \mathrm{oC}$ 


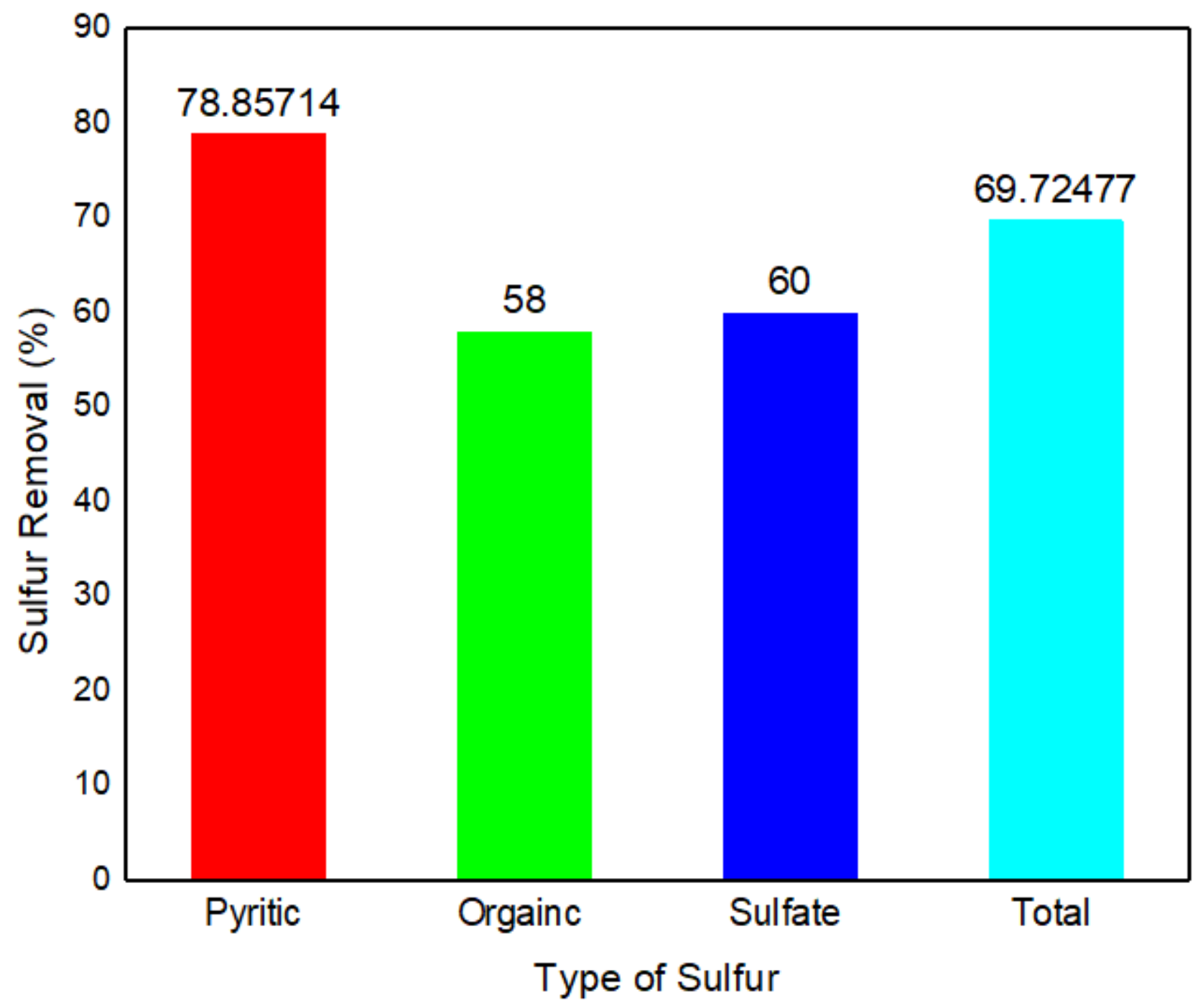

Figure 12

Sulfur removal \% at maximum agitation speed $1500 \mathrm{rpm}$, oxygen partial pressure of 100psi, particle size $40 \mu \mathrm{m}, \mathrm{NaOH}$ concentration 0.25 Molarity, reaction time 4hours, reaction temperature $120 \mathrm{oC}$, 


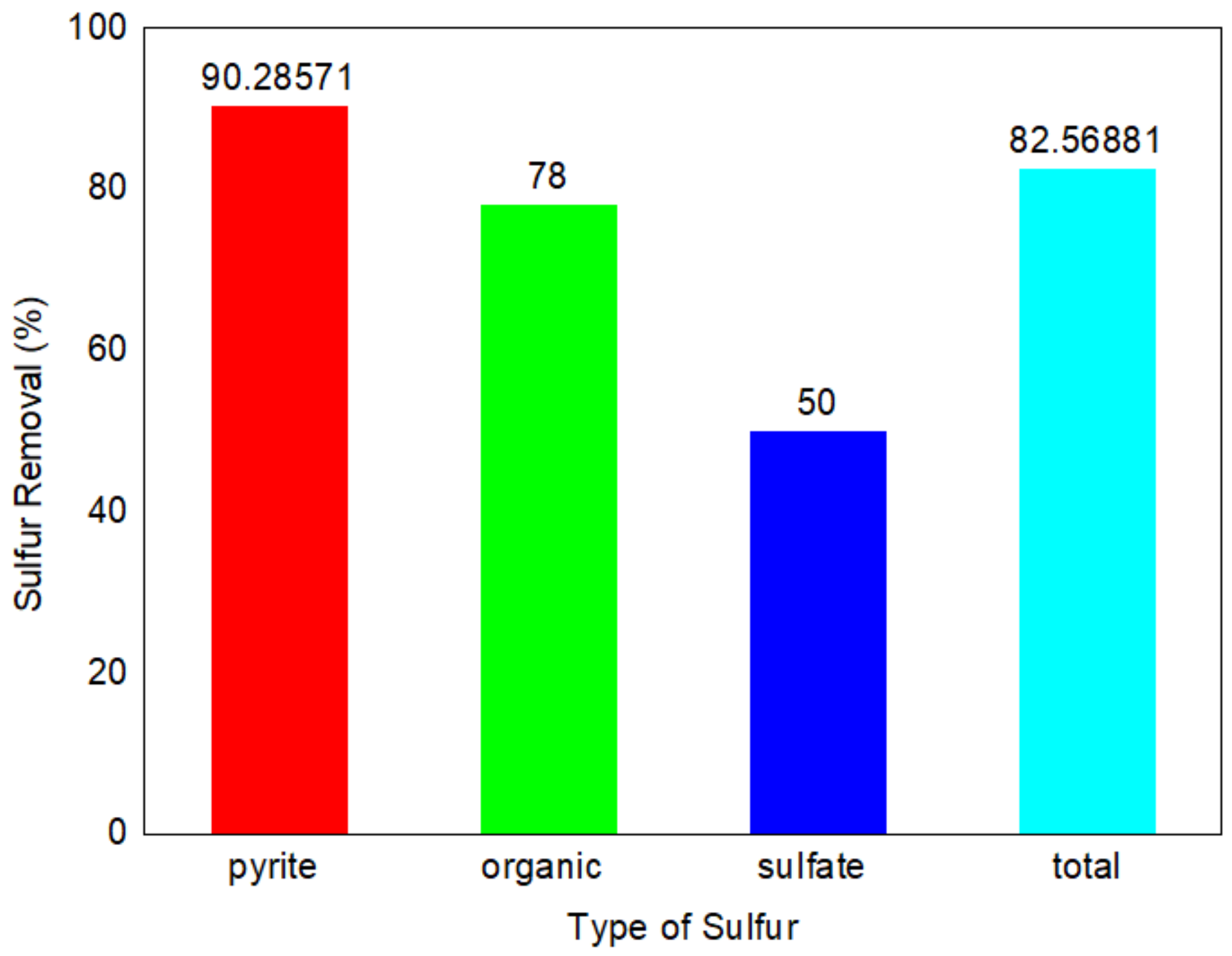

Figure 13

Sulfur removal \% by optimized reaction at maximum agitation speed $2000 \mathrm{rpm}$, partial pressure of oxygen of 200psi, particle size $40 \mu \mathrm{m}, \mathrm{NaOH}$ concentration 0.25 Molarity, reaction time 3hours, reaction temperature of $120 \mathrm{oC}$. 


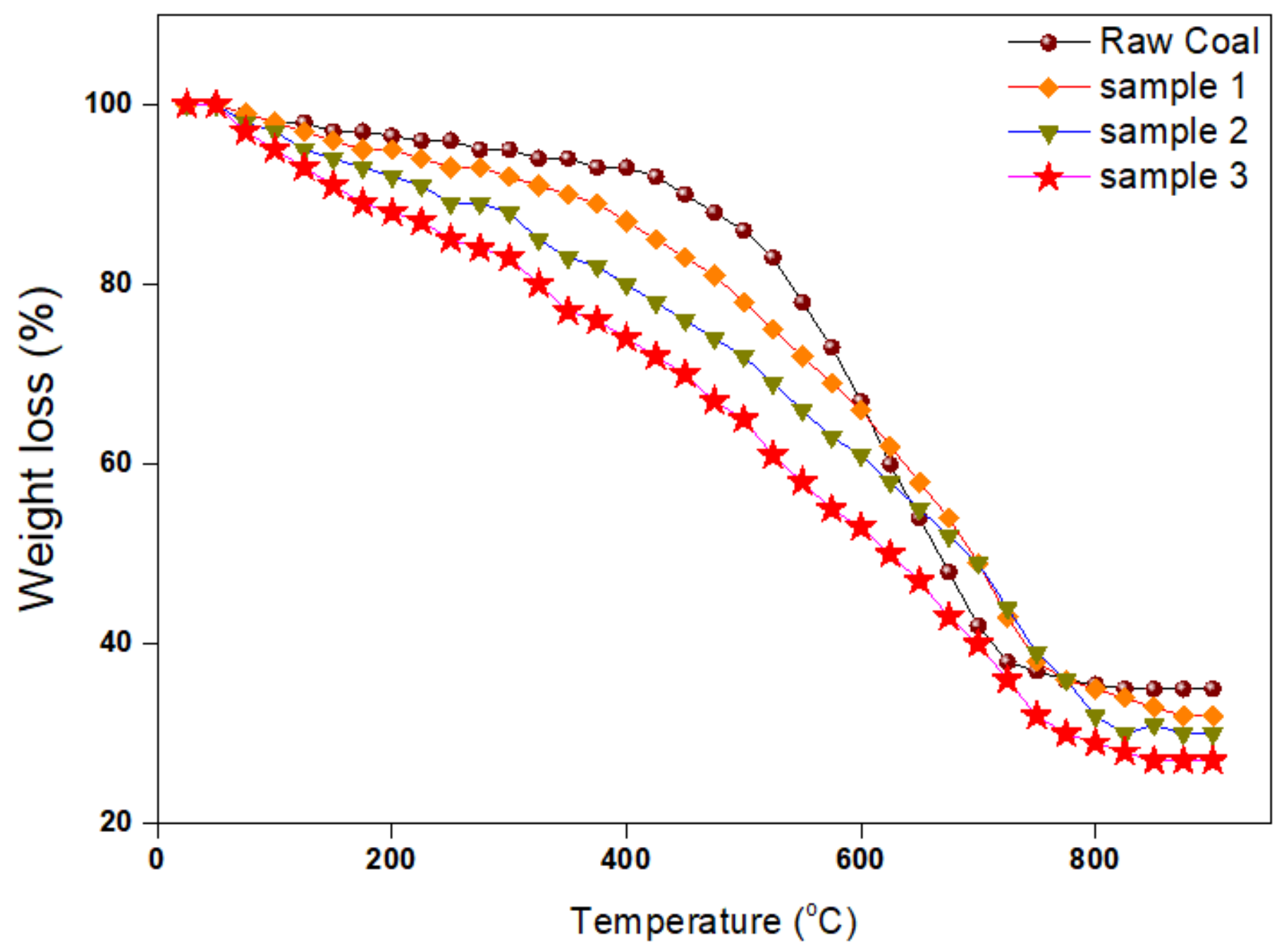

Figure 14

Thermogravimetric analysis of raw Thar coal and processed coal 


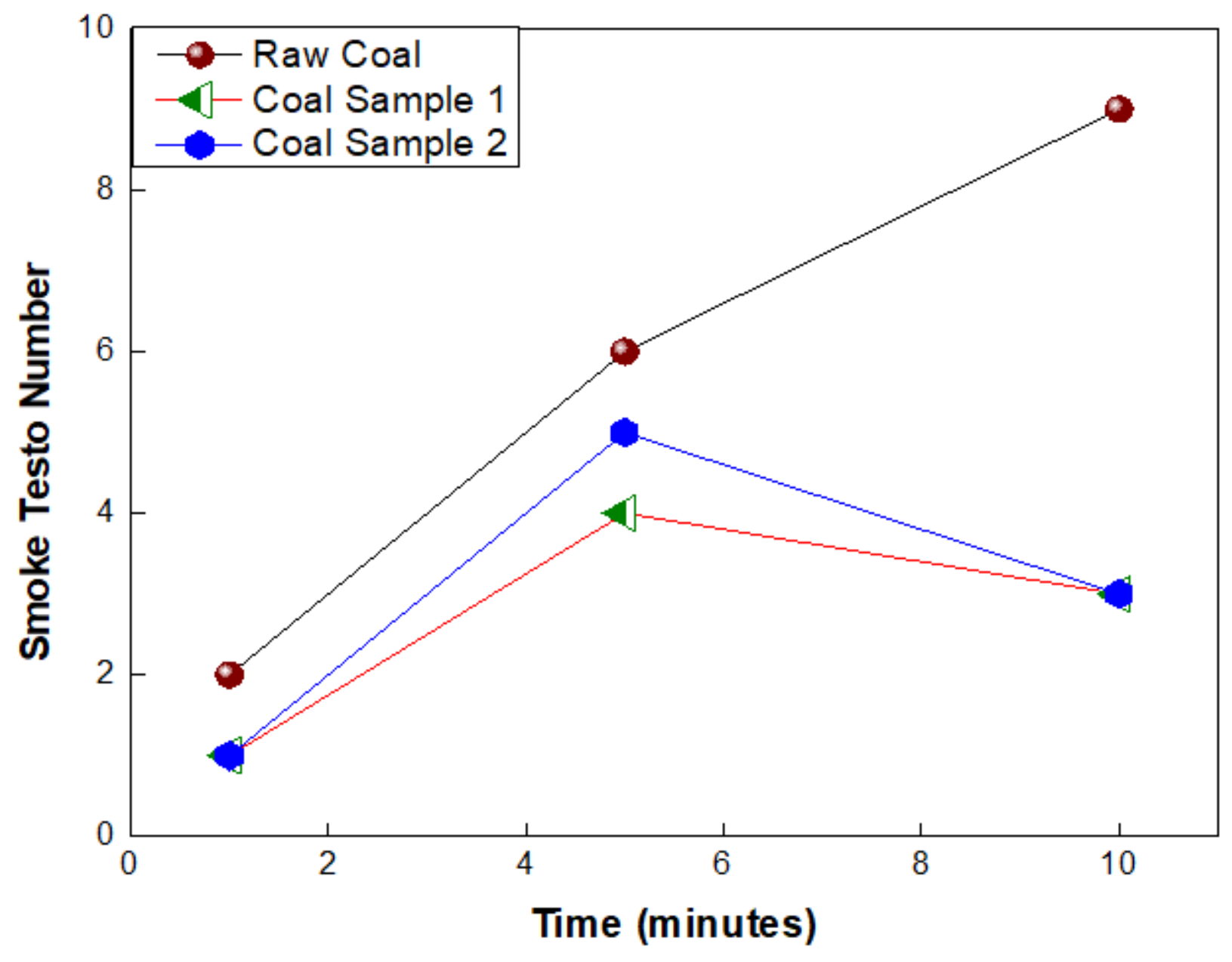

Figure 15

Testo Smoke number of raw Thar coal and processed coal 